\title{
A Study of Gross and Net Non-Performing Assets of Select Public Sector Banks in India for the Period 2007-2008 to 2017-2018
}

\author{
Abhay Korde $P h D$ \\ Advocate \\ High Court Bombay \\ Mumbai, India \\ \& \\ Alumni, JBIMS, Mumbai, India \\ E-mail: abhaykordeI4@jbims.edu \\ Kavita Laghate $P h D$ \\ Professor \& Director \\ Jamnalal Bajaj Institute of Management Studies \\ University of Mumbai \\ Mumbai, India \\ E-mail:kavitalaghate@jbims.edu
}

\begin{abstract}
The Non-Performing Assets (NPAs) are considered as one of the important parameters for anlysing the health of the Indian Banks. The Authors have taken a look at the Literature Reviews related to the non-performing assets related studies looked into by other Research Scholars. The authors in this research study has made an attempt to study the secondary data related to Gross and Net Non-Performing Assets or Loans of select Banks in India, which is available in the public domain of the regulators of Indian Banks i.e. Reserve Bank of India (RBI) from April 2007 to March 2018 and has performed the $\mathrm{ABC}$ analysis as per cumulative (decreasing method) to study the performance and the management and governance of those Banks. Finally, the authors conclude that some of the select Indian Banks taken for study appear in the various Groups formulated for study i.e. Group A (Poor Performance), Group B (Satisfactory Performance) and Group C (Good Performance) are thus a matter of great concern to the economy of the country.
\end{abstract}

Keywords: Assets, Banks, Governance, Gross, Indian, Loans, Management, Net, Performance.

\section{Introduction}

The entire world has accepted that the country is galloping towards being the third largest economy of the world in the near future and therefore, the financial and banking system or sector in India is required to play an important role to shape up its economy. The main business of the banking system is to cater to the financial needs of the business and individuals, but now it has also been vested with the responsibility to support other activities like the Insurance and supporting various schemes announced by the government from time to time. The Banks are required not only to safeguard the deposits of the Customers but also required to ensure that the loans or advances given are not defrauded by the business community or certain individuals for their own vested interest, as it has been observed in the recent past. Therefore, to arrive at the strength of the banking system in India the Non-Performing Assets (NPAs) are considered as one of the important parameter for analysis. A sound banking and financial system is therefore, needs now.

\section{Literature Review}

The objective of study of Sanjeev (2007) was to identify critical factors, which were responsible for the loans of the banks to go bad in the Indian commercial banking system. The Methodology adopted for the study was mainly related to primary data collected from credit managers of banks operating in India. Their study revealed that the external factors have a higher influence compared to the internal factors, which was also very surprising. The Economic downturn and willful default have been found to be most critical factor. Also the poor credit scoring skill of managers, absence of suitable administrative penalties and target completion have been found to have a significant influence amongst factors related with the loan appraisal mechanism of the banks. The seizure and disposal of collateral have found to be the toughest challenges amongst the factors related with the loan monitoring and controlling mechanism. The level of loan manager's motivation,, manpower, skill to appraise collateral, effort to reduce costs, government and political intervention and soft budget constraints have been found to have a lower influence.

However, the objective of study of Khushpatand \& Rahul (2012) was to analyze the trends in Non-Performing Assets (NPAs) in the Indian Banking Sector from 2004-20I I, to assess the contributing factors to the NPA in the Indian Banking Sector and to suggest measures to halt and curtail the rising burden of NPAs. They mainly dealt with the rising burden of NPAs in Indian financial system and their likely impact and measures to minimize such adverse impact on the Indian 
banking system in particular and Indian economy in general. They were also of the view that the factor contributing to the rising NPAs is the upward shift in interest rates due to the Reserve Bank of India's (RBI) tight monetary policy for controlling inflation. The increased interest rate (floating interest) has increased the repayment burden of borrowers which is compelling them to default their interest payments and repayments. The authors concluded that the banks should focus on recovery of existing loans and be more circumspect in their credit appraisal, rescheduling of large corporate loans as rising interest cost and falling sales revenue may result in widespread defaults of corporate loans, phasing out of priority sector loans to $10 \%$ of the total loans so as to reduce the burden of NPAs in priority sector, making priority sector loans need-based rather than target based which results in poor credit appraisal and loan default. The authors arrived at a conclusion that the major contributor to the NPAs in banking sector was agricultural sector. NPAs in non-priority sectors are likely to increase due to decelerating trends in major sectors like manufacturing and infrastructure and slowing down of economy during 2012.

\section{Definitions}

3.I Non-Performing Assets (NPA) or Non-Performing Loans (NPL)

The non-performing assets or loans in the books of the Banks are the loan that has been defaulted by the borrower. As per the regulators of Banks in India the loan becomes non-performing it is in default for 90 days.

\subsection{Gross Non-Performing Assets (GNPA) or Gross Non-Performing Loans (GNPL)}

It is the total number of Non-Performing Assets or Loans of the Banks added together.

\subsection{Net Non-Performing Assets (NNPA) or Net Non-Performing Loans (NNPL)}

Net Non-Performing Assets or NNPL is the total of actual bad assets minus the provision left aside. The Indian Banks Regulator defines Net NPA or NPL as Net NPA or NPL = Gross NPA or NPL - (Balance in Interest Suspense Account + Deposit Insurance and Credit Guarantee Corporation (DICGC)/Export Credit Guarantee Corporation of India (ECGC) claims received and held pending adjustment + Part payment received and kept in suspense account + Total provisions held.

\section{Objective of Research Study}

- To study and analyze Select Indian Bank's Gross Non-Performing Assets or Loans and Net Non-Performing Assets or Loans from April 2007 to March 2018.

- To do comparative analysis of the Select Indian Bank's Gross Non-Performing Assets or Loans and Net NonPerforming Assets or Loans from April 2007 to March 2018.

- To analyse the management and governance or performance of directing and controlling of the Select Indian Bank's from April 2007 to March 2018.

\section{Methodology Adopted For Research}

Banking sector is analysed using secondary data available from Reserve Bank of India (RBI) and Money Control websites. It is an Analytical Research. The data was collected for the period of April 2007 to March 2018 i.e. 2007-2008 to 20I72018. Assuming that the figures are given by the apex body of the banking sector, i.e. Reserve Bank of India and therefore, $\mathrm{ABC}$ analysis is attempted on that.

\section{Analysis of Data}

\section{I The defaulted loans of the Select Indian Bank's from April 2007 to March 2018 were done according to the increasing} method as given in Appendix $A$ and respectively.

\subsection{The Group ranking of the select Indian Bank's Defaulted Loans from April 2007 to March 2018 was as per the results arrived from the $A B C$ Analysis method as given in Appendix $A, B$ and $C$, $D$ respectively.}

Table I. Ranking of Gross Non-Performing Assets or Loans of the select Indian Banks from April 2007 to March 2018 (Bank with Highest Gross Non-Performing Loans is Rated I).

\begin{tabular}{|c|c|c|c|c|c|c|c|c|c|c|c|c|}
\hline $\begin{array}{l}\text { Name of the } \\
\text { Select Indian } \\
\text { Banks }\end{array}$ & $\begin{array}{l}2007- \\
2008\end{array}$ & & $\begin{array}{l}2008- \\
2009\end{array}$ & $\begin{array}{l}2009- \\
2010\end{array}$ & $\begin{array}{l}2010- \\
2011\end{array}$ & $\begin{array}{l}2011- \\
2012\end{array}$ & $\begin{array}{l}2012- \\
2013\end{array}$ & $\begin{array}{l}2013- \\
2014\end{array}$ & $\begin{array}{l}2014- \\
2015\end{array}$ & $\begin{array}{l}2015- \\
2016\end{array}$ & $\begin{array}{l}2016- \\
2017\end{array}$ & $\begin{array}{l}2017- \\
2018\end{array}$ \\
\hline $\begin{array}{l}\text { State Bank of } \\
\text { India }\end{array}$ & & $\bar{I}$ & & $\bar{I}$ & $\overline{\mathrm{I}}$ & 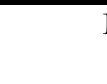 & $\bar{I}$ & $\bar{I}$ & $\bar{I}$ & & $\bar{I}$ & $\mathrm{I}$ \\
\hline $\begin{array}{l}\text { Punjab } \\
\text { National } \\
\text { Bank }\end{array}$ & & 2 & & $\overline{4}$ & 3 & 2 & 2 & 2 & 2 & & 2 & 2 \\
\hline
\end{tabular}




\begin{tabular}{|c|c|c|c|c|c|c|c|c|c|c|c|}
\hline $\begin{array}{l}\text { Central Bank } \\
\text { of India }\end{array}$ & 3 & 4 & 7 & II & 3 & 4 & 5 & 9 & 9 & 9 & 9 \\
\hline $\begin{array}{ll}\text { Bank } & \text { of } \\
\text { Baroda } & \\
\end{array}$ & 4 & 8 & 8 & 5 & 7 & 5 & 3 & 4 & 4 & 5 & 4 \\
\hline Bank of India & 5 & 3 & 2 & 2 & 4 & 3 & 4 & 3 & 3 & 3 & 3 \\
\hline $\begin{array}{l}\text { Syndicate } \\
\text { Bank }\end{array}$ & 6 & 9 & 10 & IO & 12 & I5 & 16 & 15 & I4 & $\mathrm{I} 4$ & $\mathrm{I} 4$ \\
\hline $\begin{array}{l}\text { Union Bank } \\
\text { of India }\end{array}$ & 7 & 7 & 5 & 4 & 5 & 9 & 7 & 7 & 8 & 8 & 6 \\
\hline UCO Bank & 8 & I0 & II & 6 & 8 & 6 & $\mathrm{I} 2$ & I0 & 10 & II & 10 \\
\hline IDBI Bank & 9 & II & 9 & 9 & 6 & 8 & 6 & 8 & 7 & 4 & 5 \\
\hline $\begin{array}{l}\text { Oriental } \\
\text { Bank of } \\
\text { Commerce }\end{array}$ & 10 & 13 & $\mathrm{I} 2$ & $\mathrm{I} 2$ & II & $\mathrm{I} 2$ & $\mathrm{I} 4$ & $2 \mathrm{I}$ & 12 & I0 & 13 \\
\hline Canara Bank & II & 5 & 6 & 8 & 9 & I0 & 10 & 6 & 5 & 7 & 7 \\
\hline $\begin{array}{l}\text { Allahabad } \\
\text { Bank }\end{array}$ & 12 & 12 & I4 & I3 & I4 & II & 9 & II & II & 12 & 12 \\
\hline $\begin{array}{l}\text { Indian } \\
\text { Overseas } \\
\text { Bank } \\
\end{array}$ & I3 & 6 & 3 & 7 & I0 & 7 & 8 & 5 & 6 & 6 & 8 \\
\hline $\begin{array}{l}\text { Bank of } \\
\text { Maharashtra }\end{array}$ & I4 & I5 & I5 & 16 & I8 & $2 \mathrm{I}$ & I8 & 16 & 16 & I5 & 16 \\
\hline $\begin{array}{l}\text { United Bank } \\
\text { of India }\end{array}$ & I5 & $\mathrm{I} 4$ & I3 & $\mathrm{I} 4$ & I3 & 16 & II & $\mathrm{I} 4$ & I7 & 18 & 17 \\
\hline $\begin{array}{l}\text { Corporation } \\
\text { Bank } \\
\end{array}$ & I6 & I8 & I7 & 19 & I9 & I7 & I5 & 12 & I3 & 16 & I5 \\
\hline Dena Bank & I7 & I7 & 18 & 18 & 20 & 20 & 19 & I8 & I9 & I7 & I8 \\
\hline Vijaya Bank & I8 & 16 & 16 & I5 & I7 & 19 & $2 \mathrm{I}$ & 20 & 20 & 20 & 21 \\
\hline Indian Bank & 19 & I9 & 19 & 20 & I5 & $\mathrm{I} 4$ & 17 & 17 & I8 & 19 & 19 \\
\hline Andhra Bank & 20 & 20 & 20 & 17 & I6 & I3 & $\mathrm{I3}$ & 13 & I5 & I3 & II \\
\hline $\begin{array}{l}\text { Punjab and } \\
\text { Sind Bank }\end{array}$ & $2 \mathrm{I}$ & $2 \mathrm{I}$ & $2 \mathrm{I}$ & $2 \mathrm{I}$ & $2 \mathrm{I}$ & I8 & 20 & 19 & $2 \mathrm{I}$ & $2 \mathrm{I}$ & 20 \\
\hline
\end{tabular}

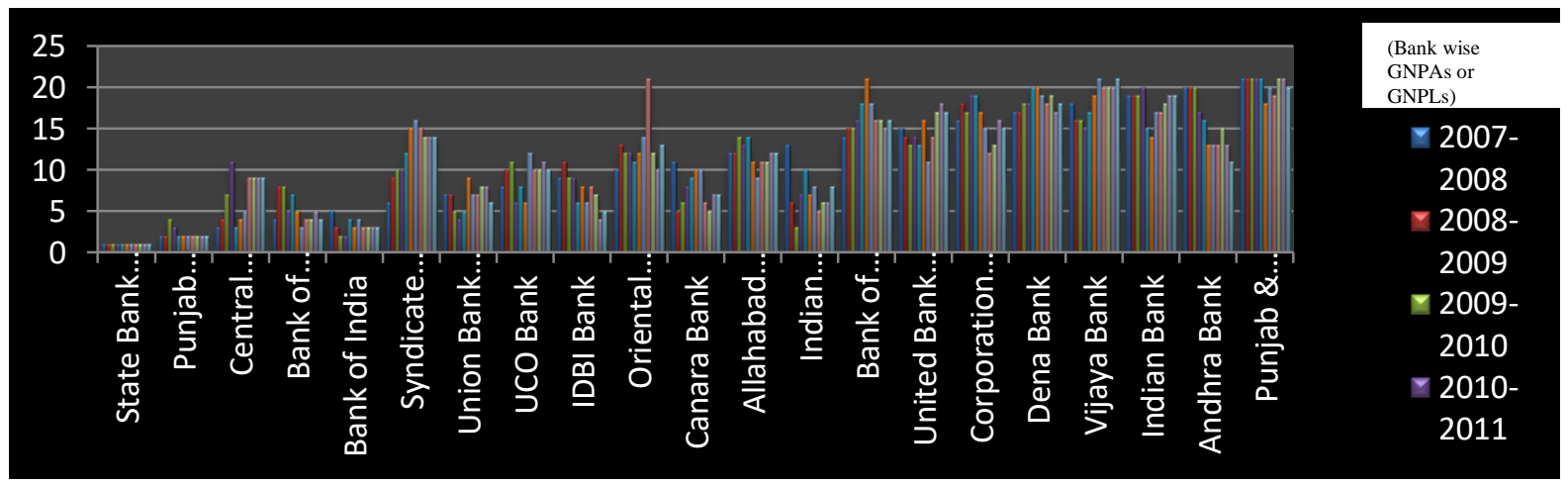

Figure I. Ranking of Gross Non-Performing Assets or Loans of the select Indian Banks from April 2007 to May 2018

Table 2. Ranking of Net Non-Performing Assets or Loans of the select Indian Banks from April 2007 to March 2018 (Bank with Highest Net Non-Performing Assets or Loans is Rated I).

\begin{tabular}{|c|c|c|c|c|c|c|c|c|c|c|c|}
\hline $\begin{array}{l}\text { Name of } \\
\text { the Bank }\end{array}$ & $\begin{array}{l}2007- \\
2008\end{array}$ & $\begin{array}{l}2008- \\
2009\end{array}$ & $\begin{array}{l}2009- \\
2010\end{array}$ & $\begin{array}{l}2010- \\
2011\end{array}$ & $\begin{array}{l}2011- \\
2012\end{array}$ & $\begin{array}{l}2012- \\
2013\end{array}$ & $\begin{array}{l}2013- \\
2014\end{array}$ & $\begin{array}{l}2014- \\
2015\end{array}$ & $\begin{array}{l}2015- \\
2016\end{array}$ & $\begin{array}{l}2016- \\
2017\end{array}$ & $\begin{array}{l}2017- \\
2018\end{array}$ \\
\hline $\begin{array}{l}\text { State Bank } \\
\text { of India }\end{array}$ & I & I & I & I & I & 1 & I & I & I & I & I \\
\hline
\end{tabular}




\begin{tabular}{|c|c|c|c|c|c|c|c|c|c|c|c|}
\hline UCO Bank & 2 & 6 & 7 & 5 & 9 & 8 & I3 & 9 & 10 & $\mathrm{I} 4$ & $\overline{\text { II }}$ \\
\hline IDBI Bank & 3 & 5 & 5 & 7 & 7 & II & I0 & I0 & 7 & 4 & 3 \\
\hline $\begin{array}{l}\text { Central Bank } \\
\text { of India }\end{array}$ & 4 & 3 & II & II & 2 & 5 & 4 & 8 & 9 & 9 & 9 \\
\hline Canara Bank & 5 & 2 & 4 & 2 & 5 & 4 & 6 & 5 & 4 & 5 & 4 \\
\hline $\begin{array}{l}\text { Punjab } \\
\text { National } \\
\text { Bank }\end{array}$ & 6 & I7 & 6 & 3 & 3 & 2 & 2 & 2 & 2 & 2 & 2 \\
\hline $\begin{array}{l}\text { Syndicate } \\
\text { Bank }\end{array}$ & 7 & 7 & 9 & 9 & I3 & I7 & 17 & 16 & $\mathrm{I} 4$ & I5 & 13 \\
\hline $\begin{array}{l}\text { Bank of } \\
\text { India }\end{array}$ & 8 & 8 & 2 & 4 & 4 & 3 & 3 & 3 & 3 & 3 & 5 \\
\hline $\begin{array}{l}\text { Oriental } \\
\text { Bank of } \\
\text { Commerce }\end{array}$ & 9 & I I & 12 & IO & 8 & $\mathrm{I} 2$ & $\mathrm{I} 2$ & $\mathrm{I} 2$ & 12 & I0 & 10 \\
\hline $\begin{array}{ll}\text { Bank } & \text { of } \\
\text { Baroda } & \end{array}$ & 10 & 10 & 14 & $\mathrm{I} 2$ & II & 6 & 5 & 6 & 5 & 8 & 7 \\
\hline $\begin{array}{l}\text { Allahabad } \\
\text { Bank }\end{array}$ & II & 12 & 16 & I5 & I4 & 7 & 7 & II & II & II & 15 \\
\hline $\begin{array}{l}\text { Indian } \\
\text { Overseas } \\
\text { Bank }\end{array}$ & 12 & 4 & 3 & 8 & 10 & 9 & 8 & 4 & 6 & 6 & 8 \\
\hline $\begin{array}{l}\text { United Bank } \\
\text { of India }\end{array}$ & I3 & 9 & 10 & 13 & I5 & I6 & II & I5 & 16 & 18 & 16 \\
\hline $\begin{array}{l}\text { Bank of } \\
\text { Maharashtra }\end{array}$ & 14 & 16 & I3 & 16 & $2 \mathrm{I}$ & $2 \mathrm{I}$ & 20 & 14 & 15 & 13 & 17 \\
\hline Dena Bank & 15 & $\mathrm{I} 4$ & I7 & I7 & I9 & 19 & 19 & I9 & 19 & I7 & I8 \\
\hline Vijaya Bank & 16 & I5 & I5 & I4 & 16 & 20 & $2 \mathrm{I}$ & $2 \mathrm{I}$ & 20 & $2 \mathrm{I}$ & 20 \\
\hline $\begin{array}{l}\text { Union Bank } \\
\text { of India }\end{array}$ & 17 & 13 & 8 & 6 & 6 & I0 & 9 & 7 & 8 & 7 & 6 \\
\hline $\begin{array}{l}\text { Corporation } \\
\text { Bank } \\
\end{array}$ & I8 & 18 & I8 & I8 & I7 & I6 & I5 & 13 & 13 & 12 & $\mathrm{I} 2$ \\
\hline Indian Bank & 19 & 19 & 19 & I9 & 12 & $\mathrm{I} 4$ & 16 & 18 & 18 & 19 & 19 \\
\hline $\begin{array}{l}\text { Punjab and } \\
\text { Sind Bank }\end{array}$ & 20 & $2 \mathrm{I}$ & 20 & $2 \mathrm{I}$ & 20 & 18 & 18 & 20 & $2 \mathrm{I}$ & 20 & $2 \mathrm{I}$ \\
\hline Andhra Bank & $2 \mathrm{I}$ & 20 & $2 \mathrm{I}$ & 20 & I8 & I3 & $\mathrm{I} 4$ & 17 & 17 & 16 & $\mathrm{I} 4$ \\
\hline
\end{tabular}

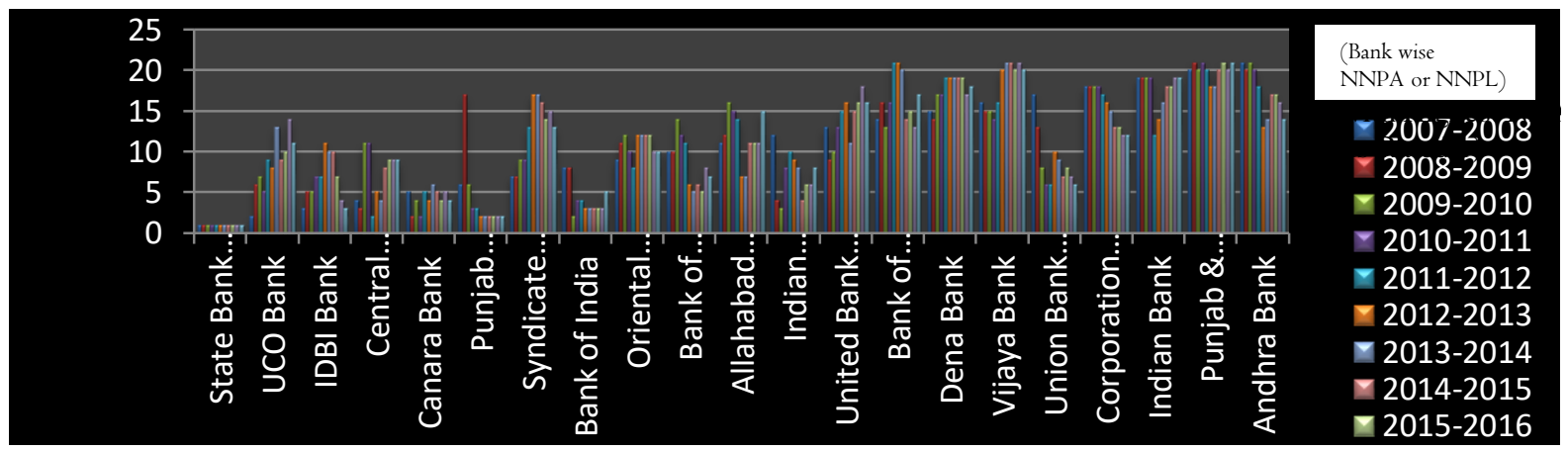

Figure 2. Ranking of Net Non-Performing Assets or Loans of the select Indian Banks from April 2007 to March 2018

\subsection{Select Indian Banks - Gross and Net Non-Performing Assets or Loans -Analysis}

For the purpose of analyzing the select Indian Banks, and deciding the management performance and governance, it was decided to have ABC Analysis of three groups from the cumulative (decreasing method) Gross \& Net NPAs or NPLs of the select Indian Banks.

Group A - I - 70 - Poor management and governance or performance of directing and controlling. 
Group - B - 7I - 90 - Satisfactory management and governance or performance of directing and controlling.

Group - C - 9I - IO0 - Good management and governance or performance of directing and controlling.

\subsection{Group - A}

State Bank of India, Punjab National Bank, Bank of India and Central Bank of India were in Group A i.e. I-70\% (Poor performance) most the years in Gross Non-Performing Assets or Loans and Net Non-Performing Assets or Loans from April 2007 to March 2018. An analysis of this four Bank's movement is studied and it is observed as below:

\subsection{I.I State Bank of India}

From August 2008 to April 2017, along with its seven subsidiary banks and Bhartiya Mahila Bank were merged into State Bank of India. However, it can be observed from Appendix A and B that there was not much impact on the NonPerforming Assets or Loans during that period.

Table 3. Gross \& Net Non-Performing Assets or Loans as on March 2018

\begin{tabular}{|c|c|c|c|c|c|c|c|}
\hline \multirow[b]{3}{*}{ Year } & & & & & & \multicolumn{2}{|c|}{ Rs. Million } \\
\hline & \multicolumn{5}{|c|}{ Gross Non-Performing Loans } & Net Non-Perfo & ming Loans \\
\hline & $\begin{array}{l}\text { Last } \\
\text { Year's Out } \\
\text { standing }\end{array}$ & $\begin{array}{l}\text { Added } \\
\text { during the } \\
\text { year }\end{array}$ & $\begin{array}{l}\text { Reduced } \\
\text { during the } \\
\text { year }\end{array}$ & Written-Off & Present Year & Last Year & Present Year \\
\hline $2017-18$ & II23430 & I603037 & 90238 & 401954 & 2234275 & 582774 & I I08547 \\
\hline
\end{tabular}

Source: https://www.rbi.org.in

Table 4. Details of Chairman of State Bank of India from April 2007 to March 2018

\begin{tabular}{llll}
\hline Sl.No. & \multicolumn{1}{c}{ Name } & \multicolumn{2}{c}{ Period } \\
\hline & & From & To \\
\hline I. & Shri O.P.Bhatt & July 2006 & March 20I I \\
\hline 2. & Shri Pratip Chaudhari & April 20II & September 20I3 \\
\hline 3. & Smt. Arundhati Bhattacharya & October 20I3 & October 2017 \\
\hline 4. & Shri Rajnish Kumar & October 20I7 & Till Date \\
\hline
\end{tabular}

It can be observed from table 3 that the Gross Non-Performing Assets or Loans during the previous year ending i.e. March 2017 was Rs.II23430 Million and during the year April 2017 to March 2018 Rs.I603037 Million were added. During the year Bank had reduced Rs.90238 Million and written off Rs.401954 Million. The Gross Non-Performing Assets or Loans of the Bank at the end of March 2018 stood at Rs.2234275 Million. As regards the Net Non-Performing Assets or Loans during the previous year ending was Rs.582774 Million and during the year ending March 2018 it stood at Rs.II08547 Million. It can also be observed that during the study period April 2007 to March 2018 the Bank topped in Group A, during the entire period.

\subsubsection{Punjab National Bank}

It is interesting to note that there were no other Banks merged into Punjab National Bank from April 2007 to March 2018. The Gross and Net Non-Performing Assets or Loans of the Bank were amongst the top two for the study period i.e. April 2007 to March 2018 as can be seen from Appendix A,B,C and D.

Table 5. Gross \& Net Non-Performing Assets or Loans as on March 2018

Rs. Million

\begin{tabular}{|c|c|c|c|c|c|c|c|}
\hline \multirow[b]{2}{*}{ Year } & \multicolumn{5}{|c|}{ Gross Non-Performing Assets or Loans } & \multicolumn{2}{|c|}{$\begin{array}{c}\text { Net Non-Performing Assets or } \\
\text { Loans }\end{array}$} \\
\hline & $\begin{array}{l}\text { Last } \\
\text { Year's } \\
\text { Out } \\
\text { standing }\end{array}$ & $\begin{array}{l}\text { Added } \\
\text { during the } \\
\text { year }\end{array}$ & $\begin{array}{l}\text { Reduced } \\
\text { during the } \\
\text { year }\end{array}$ & Written-Off & Present Year & Last Year & Present Year \\
\hline 2017-18 & 553705 & 442743 & 56175 & 74072 & 866201 & 327021 & 486843 \\
\hline
\end{tabular}

Source: https://www.rbi.org.in 
Table 6. Details of Chairman and Managing Director and Chief Executive Officer-Punjab National Bank from April 2007 to March 2018

\begin{tabular}{cccc}
\hline Sl.No. & Name & \multicolumn{2}{c}{ Period } \\
\hline & & From & To \\
\hline I. & Dr. K.C.Chakravarty & 2007 & June 2009 \\
\hline 2. & Mr. K.R.Kamath & October 2009 & October 2014 \\
\hline 3. & $\begin{array}{c}\text { Mr. Gauri Shankar, Executive Director } \\
\text { (Acting Chairman and Managing Director) }\end{array}$ & February 2015 & August 2015 \\
\hline 4. & Mrs. Usha Ananthasubramanian & August 2015 & May 2017 \\
\hline 5. & Mr. Sunil Mehta & May 2017 & September 2019 \\
\hline
\end{tabular}

It can be observed from table 5 that the Gross Non-Performing Loans during the previous year ending i.e. March 2017 was Rs.553705 Million and during the year April 2017 to March 2018 Rs.442743 Million were added. During the year the Bank had reduced Rs.56I75 Million and written off Rs.74072 Million. The Gross Non-Performing Assets or Loans of the Bank stood at the end of April 2018 to Rs.86620I Million. As regards the Net Non-Performing Assets or Loans during the previous year ending was Rs.32702I Million and during the year ending March 2018 it stood at Rs.486843 Million. It can also be observed that during the study period April 2007 to March 2018 the Bank was mostly in Group A.

\subsubsection{Bank of India}

The Gross and Net Non-Performing Assets or Loans of the Bank were amongst the top three for the study period i.e. April 2007 to March 2018 as can be seen from Appendix A,B,C and D.

Table 7. Gross \& Net Non-Performing Assets or Loans as on March 2018

Rs. Million

\begin{tabular}{|c|c|c|c|c|c|c|c|}
\hline & \multicolumn{5}{|c|}{ Gross Non-Performing Assets or Loans } & \multicolumn{2}{|c|}{$\begin{array}{c}\text { Net Non-Performing Assets or } \\
\text { Loans }\end{array}$} \\
\hline Year & $\begin{array}{l}\text { Last } \\
\text { Year's } \\
\text { Out } \\
\text { standing }\end{array}$ & $\begin{array}{l}\text { Added } \\
\text { during the } \\
\text { year }\end{array}$ & $\begin{array}{l}\text { Reduced } \\
\text { during the } \\
\text { year }\end{array}$ & Written-Off & Present Year & Last Year & Present Year \\
\hline $\begin{array}{l}2017- \\
2018\end{array}$ & 520445 & 255805 & 62518 & 90448 & 623285 & 253050 & 282073 \\
\hline
\end{tabular}

Source: https://www.rbi.org.in

Table 8. Details of Chairman and Managing Director and Chief Executive Officer Bank of India from April 2007 to March 2018

\begin{tabular}{llll}
\hline Sl.No. & \multicolumn{1}{c}{ Name } & From & To \\
\hline & & August 2003 & September 2012 \\
\hline I. & Mr. Alok K. Misra & November 2012 & May 2015 \\
\hline 2. & Mrs. V.R.Iyer & February 20I5 & August 2015 \\
\hline 3. & Mr. Melwyn Rego & August 2015 & May 2017 \\
\hline 4. & Mrs. Usha Ananthasubramanian & May 2017 & June 2019 \\
\hline 5. & Mr. Dinabandhu Mohapatra & Meriod \\
\hline
\end{tabular}

It can be observed from table 7 that the Gross Non-Performing Loans during the previous year ending i.e. March 2017 was Rs.520445 Million and during the year April 2017 to March 2018 Rs.255805 Million were added. During the year the Bank had reduced Rs.625I8 Million and written off Rs.90448 Million. The Gross Non-Performing Assets or Loans of the Bank at the end of March 2018 stood at Rs.623285 Million. As regards the Net Non-Performing Assets or Loans during the previous year ending was Rs.253050 Million and during the year ending March 2018 it stood at Rs.282074 Million. It can also be observed that during the study period April 2007 to March 2018 the Bank was mostly in Group A.

\subsubsection{Central Bank of India}

The Gross and Net Non-Performing Assets or Loans of the Bank were amongst the top four for the study period i.e April March 2007 to March 2018 as can be seen from Appendix A,B,C and D. 
Table 9. Gross \& Net Non-Performing Assets or Loans as on March 2018

\begin{tabular}{|c|c|c|c|c|c|c|c|}
\hline & & & & & & & ion \\
\hline & & Gross $N$ & n-Performing & ssets or Loans & & Net Non & $\begin{array}{l}\text { ming Assets or } \\
\text { ns }\end{array}$ \\
\hline Year & $\begin{array}{l}\text { Last } \\
\text { Year's } \\
\text { Out } \\
\text { standing }\end{array}$ & $\begin{array}{l}\text { Added } \\
\text { during the } \\
\text { year }\end{array}$ & $\begin{array}{l}\text { Reduced } \\
\text { during the } \\
\text { year }\end{array}$ & Written-Off & Present Year & Last Year & Present Year \\
\hline $\begin{array}{l}2017- \\
2018\end{array}$ & 272513 & 170712 & 32683 & 29236 & 381307 & I42I78 & 173779 \\
\hline
\end{tabular}

Source: https://www.rbi.org.in

Table I0. Details of Chairman and Managing Director and Chief Executive Officer -

Central Bank of India from April 2007 to March 2018

\begin{tabular}{|c|c|c|c|}
\hline Sl.No. & Name & \multicolumn{2}{|c|}{ Period } \\
\hline & & From & To \\
\hline $\mathrm{I}$. & Ms. H.A.Daruwalla & June 2005 & December 2008 \\
\hline 2. & Mr. S. Sridharan & March 2009 & May 20I I \\
\hline 3. & Mr. M.V.Tanksale & June 20I I & July 2013 \\
\hline 4. & Mr. Rajeev Rishi & I August 2013 & 31 August 2018 \\
\hline 5. & Mr. Pallav Mohapatra & September 2018 & Till Date \\
\hline
\end{tabular}

It can be observed from table 9 that the Gross Non-Performing Assets or Loans during the previous year ending i..e March 2017 was Rs.2725I3 Million and during the year April 2017 to March 2018 Rs.I707I2 Million were added. During the year the Bank had reduced Rs.32683 Million and written off Rs.29236 Million. The Gross Non-Performing Assets or Loans of the Bank at the end of March 2018 stood at Rs.381307 Million. As regards the Net Non-Performing Assets or Loans during the previous year ending was Rs.I42178 Million and during the year ending March 2018 it stood at Rs.I73779 Million. It can also be observed that during the study period April 2007 to March 2018 the Bank was mostly in Group A.

\subsubsection{Group - B}

Canara Bank and Bank of Maharashtra - were in Group B i.e. 7I - 90\% (Satisfactory Performance) most of the years in Gross NPAs and Net NPAs during the period of study i.e. 2007-2008 to 2017-2018. An analysis of movement of two Banks i.e. Canara Bank and Bank of Maharashtra is studied and it is observed as below:

\subsubsection{Canara Bank}

The Gross and Net Non-Performing Assets or Loans of the Bank were fluctuated in various rankings and was mostly in Group B during the period March 2007 to April 2018, can be seen from Appendix A,B,C and D.

The Gross and Net Non-Performing Assets or Loans of the Bank were amongst the top three for the study period i.e. April 2007 to March 2018 as can be seen from Appendix A,B,C and D.

Table II. Gross \& Net Non-Performing Assets or Loans as on March 2018

Rs. Million

\begin{tabular}{llllllll}
\hline \multicolumn{9}{c}{ Gross Non-Performing Assets or Loans } & \multicolumn{2}{c}{$\begin{array}{c}\text { Net Non-Performing Assets or } \\
\text { Loans }\end{array}$} \\
\hline Year & $\begin{array}{l}\text { Last } \\
\text { Year's } \\
\text { Out } \\
\text { standing }\end{array}$ & $\begin{array}{l}\text { Added } \\
\text { during } \\
\text { year }\end{array}$ & $\begin{array}{l}\text { Reduced } \\
\text { during } \\
\text { year }\end{array}$ & Written-Off & Present Year & Last Year & Present Year \\
& 342020 & 247608 & 31847 & 83097 & 474685 & 216490 & 285424 \\
\hline $2017-$ & & & & & & & \\
\hline
\end{tabular}

Source: https://www.rbi.org.in 
Table 12. Details of Chairman and Managing Director and Chief Executive Officer Canara Bank from April 2007 to March 2018

\begin{tabular}{llll}
\hline Sl.No. & \multicolumn{1}{c}{ Name } & \multicolumn{2}{c}{ Period } \\
\hline & & From & To \\
\hline I. & Mr. M B A Rao & June 2005 & June 2008 \\
\hline 2. & Mr. A.C.Mahajan & July 2008 & July 20I0 \\
\hline 3. & Mr. S. Raman & September 20I0 & September 2012 \\
\hline 4. & Mr.R.K.Dubey & January 2013 & September 20I4 \\
\hline 5. & Mr. Shri D.N.Manoharan & 2014 & July 2015 \\
\hline 6. & Mr. Rakesh Sharma & August 2015 & July 2018 \\
\hline 7. & RA Sankara Narayanan & April 2019 & January 2020 \\
\hline
\end{tabular}

It can be observed from table II that the Gross Non-Performing Assets or Loans during the previous year ending i.e. March 2017 was Rs.342020 Million and during the year March 2017 to April 2018 Rs.247608 Million were added. During the year Bank had reduced Rs.31847 Million and written off Rs.83097 Million. The Gross Non-Performing Assets or Loans of the Bank at the end of March 2018 stood at Rs.474685 Million. As regards the Net Non-Performing Assets or Loans during the previous year ending was Rs.2I6490 Million and during the year ending March 2018 it stood at Rs.285424 Million. It can also be observed that during the study period April 2007 to March 2018 the Bank was mostly in Group B.

\subsubsection{Bank of Maharashtra}

The Gross and Net Non-Performing Assets or Loans of the Bank were fluctuated in various rankings and was mostly in Group B during the period April 2007 to March 20I8, as can be seen from Appendix A,B,C and D.

Table I3. Gross \& Net Non-Performing Loans as on March 2018

Rs. Million

\begin{tabular}{|c|c|c|c|c|c|c|c|}
\hline & \multicolumn{5}{|c|}{ Gross Non-Performing Assets or Loans } & \multicolumn{2}{|c|}{$\begin{array}{l}\text { Net Non-Performing Assets or } \\
\text { Loans }\end{array}$} \\
\hline Year & $\begin{array}{l}\text { Last } \\
\text { Year's } \\
\text { Out } \\
\text { standing }\end{array}$ & $\begin{array}{l}\text { Added } \\
\text { during the } \\
\text { year }\end{array}$ & $\begin{array}{l}\text { Reduced } \\
\text { during the } \\
\text { year }\end{array}$ & Written-Off & Present Year & Last Year & Present Year \\
\hline $\begin{array}{l}2017- \\
2018\end{array}$ & 171887 & 54349 & 20300 & 24603 & 184332 & I I33I2 & 96412 \\
\hline
\end{tabular}

$$
\text { Source: http://www.rbi.org.in }
$$

Table I4. Details of Chairman and Managing Director and Chief Executive Officer Bank of Maharashtra from April 2007 to March 2018

\begin{tabular}{llll}
\hline Sl.No. & \multicolumn{1}{c}{ Name } & \multicolumn{2}{c}{ Period } \\
\hline & & From & To \\
\hline I. & Mr. Allen Pereira & 2007 & 20I I \\
\hline 2. & Mr. Narendra Singh & February 20I2 & September 2013 \\
\hline 3. & Mr. Sushil Muhnoot & September 2013 & September 2016 \\
\hline 4. & Mr. Ravindra Marathe & September 2016 & June 2018 \\
\hline
\end{tabular}

It can be observed from table I3 that the Gross Non-Performing Assets or Loans during the previous year ending i.e. March 2017 was Rs.I7I887 Million and during the year April 2017 to March 2018 Rs54349 Millions were added. During the year Bank had reduced Rs.20300 Million and written off Rs.24603 Million. The Gross Non-Performing Assets or Loans of the Bank at the end of March 2018 stood at Rs.I84332 Million. As regards the Net Non-Performing Assets or Loans during the previous year ending was Rs.II33I2 Million and during the year ending March 2018 it stood at Rs.964I2 Million. It can also be observed that during the study period April 2007 to March 2018 the Bank was mostly in Group B. 
6.3.3 Group - C

United Bank of India and Punjab and Sind Bank - were in Group C i.e. 9I - I00\% (Good Performance) most of the years in Gross Non-Performing Assets or Loans and Net Non-Performing Assets or Loans during the period of study i.e. April 2007 to March 2018. An analysis of these two Banks movement is studied and it is observed as below:

\subsubsection{United Bank of India}

The Gross and Net Non-Performing Assets or Loans of the Bank were fluctuated mostly in Group C during the period April 2007 to March 2018, as can be seen from Appendix A,B,C and D.

TableI5. Gross \& Net Non-Performing Assets or Loans as on March 2018

Rs. Million

\begin{tabular}{|c|c|c|c|c|c|c|c|}
\hline \multirow[b]{2}{*}{ Year } & \multicolumn{5}{|c|}{ Gross Non-Performing Assets or Loans } & \multicolumn{2}{|c|}{$\begin{array}{c}\text { Net Non-Performing Assets or } \\
\text { Loans }\end{array}$} \\
\hline & $\begin{array}{l}\text { Last } \\
\text { Year's } \\
\text { Out } \\
\text { standing }\end{array}$ & $\begin{array}{l}\text { Added } \\
\text { during the } \\
\text { year }\end{array}$ & $\begin{array}{l}\text { Reduced } \\
\text { during the } \\
\text { year }\end{array}$ & Written-Off & Present Year & Last Year & Present Year \\
\hline $\begin{array}{l}2017- \\
2018\end{array}$ & $\mathrm{I09520}$ & 86063 & II39I & I8669 & $\mathrm{I} 6552 \mathrm{I}$ & 65919 & 103163 \\
\hline
\end{tabular}

Source: https://www.rbi.org.in

Table I6. Details of Chairman and Managing Director and Chief Executive Officer -

United Bank of India - From April 2007 To March 2018

\begin{tabular}{llll}
\hline Sl.No. & \multicolumn{1}{c}{ Name } & \multicolumn{2}{c}{ Period } \\
\hline \multicolumn{1}{c}{} & & From & To \\
\hline I. & Mr. P.K.Gupta & November 2008 & February 20I0 \\
\hline 2. & Mr. Bhaskar Sen & March 20I0 & 2013 \\
\hline 3. & Mrs. Archana Bhargava & April 2013 & February 20I4 \\
\hline 4. & Mr. Peturi Srinivasan & December 20I4 & June 2016 \\
\hline 5. & Mr. Pawan Kumar Bajaj & August 2016 & September 2018 \\
\hline 6. & Mr. Ashok Kumar Pradhan & October 2018 & Till Date \\
\hline
\end{tabular}

It can be observed from table 15 that the Gross Non-Performing Assets or Loans during the previous year ending i.e. March 2017 was Rs.I09520 Million and during the year April 2017 to March 2018 Rs. 86063 Millions were added. During the year Bank had reduced Rs.II39I Million and written off Rs.I8669 Million. The Gross Non-Performing Assets or Loans of the Bank at the end of March 2018 stood at Rs.I6552I Million. As regards the Net Non-Performing Assets or Loans during the previous year ending was Rs.65919 Million and during the year ending March 2018 it stood at Rs. I03I63 Million. It can also be observed that during the study period April 2007 to March 2018 the Bank was mostly in Group C.

\subsubsection{Punjab and Sind Bank}

The Gross and Net Non-Performing Assets or Loans of the Bank were mostly in Group C during the period April 2007 to March 2018, as can be seen from Appendix A, B, C and D.

Table 17. Gross \& Net Non-Performing Assets or Loans as on March 2018

\section{Rs. Million}

\begin{tabular}{|c|c|c|c|c|c|c|c|}
\hline & \multicolumn{5}{|c|}{ Gross Non-Performing Assets or Loans } & \multicolumn{2}{|c|}{$\begin{array}{l}\text { Net Non-Performing Assets or } \\
\text { Loans }\end{array}$} \\
\hline Year & $\begin{array}{l}\text { Last } \\
\text { Year's } \\
\text { Out } \\
\text { standing }\end{array}$ & $\begin{array}{l}\text { Added } \\
\text { during the } \\
\text { year }\end{array}$ & $\begin{array}{l}\text { Reduced } \\
\text { during the } \\
\text { year }\end{array}$ & Written-Off & Present Year & Last Year & Present Year \\
\hline $\begin{array}{l}2017- \\
2018\end{array}$ & 62976 & 25918 & 6279 & 4598 & 78017 & $4375 \mathrm{I}$ & 46079 \\
\hline
\end{tabular}


Table 18. Details of Chairman and Managing Director and Chief Executive Officer United Bank of India - From April 2007 to March 2018

\begin{tabular}{llll}
\hline Sl.No. & \multicolumn{1}{c}{ Name } & \multicolumn{2}{c}{ Period } \\
\hline & & From & To \\
\hline I. & Mr. S.R.P.Singh & 2007 & August 2009 \\
\hline 2. & Mr. S.G.S.Vedi & August 2009 & June 20I0 \\
\hline 3. & Mr. D.P.Singh & November 20II & January 20I4 \\
\hline 4. & Mr. Jatinder Singh & February 20I4 & December 2017 \\
\hline 5. & S Harisankar & September 2018 & Till Date \\
\hline
\end{tabular}

It can be observed from table 17 that the Gross Non-Performing Assets or Loans during the previous year ending i.e. March 2017 was Rs.62976 Million and during the year April 2017 to March 2018 Rs. 259I8 Millions were added. During the year the Banks had reduced Rs. 6279 Million and written off Rs.4598 Million. The Gross Non-Performing Loans of the Bank at the end of March 2018 stood at Rs.78017 Million. As regards the Net Non-Performing Assets or Loans during the previous year ending was Rs.4375I Million and during the year ending March 2018 it stood at Rs. 46079 Million. It can also be observed that during the study period March 2007 to April 2008 the Bank was mostly in Group C.

\section{Conclusion}

The study of select Indian Banks for the period from April 2007 to March 2018 of all the groups together concludes that some of the Banks Net Performing Assets or Loans were very high and beyond the control of the Banks. The Banks have also been defrauded by large borrowers which have brought more strain on its assets. In some cases from the study it indicates that the performance of the Bank's management was one of the reasons for rise in non-performing assets or loans and also it can be seen that there were no heads in respect of some Banks during the study period and it is a matter of great concern. It is therefore, concluded that there should be a strong management for better results and governance and the Regulators must also have strong supervisory control and policies put in place for better results. Since the Banks under study are formed under the law of the Government, it becomes necessary for the Government to have in place heads for all the Banks, so that decision making becomes easier and also those large borrowers who are defrauding their loans should be also strictly dealt with. It is necessary to have a sound financial and banking system to strengthen the economy of the country.

\section{Limitations}

Only few selected banks are analyzed. Only the government banks were taken up for study and other type of banks i.e. Private, Co-operative and Foreign are not part of study. The qualitative aspect of the banking sector and the political environment prevailing in the country is also not part of the research study. It will be therefore, interesting to study the performance and management of the Banks after another five years after the merger of government banks into 4 to 5 big banks.

\section{References}

Sanjeev, G. M. (2007). Non-Performing Assets in Commercial Banks. Journal of Management Research, 7(I),South Asia Publications.

Khushpatand J. S., \& Rahul, C. G. (2012). Managing Business in Turbulent Times. JBIMS, Mumbai Journal, Excel India Publishers, New Delhi

Retrieved from https://www.rbi.org.in

Retrieved from http://www.moneycontrol.com

Retrieved from Select Indian Banks Websites and Annual Reports. 
Appendix - A

ABC Analysis of Gross Non-Performing Assets (GNPA) or Loans of select Indian Public Sector Banks for the period April 2007 to March 2018

Rs. Million

\begin{tabular}{|c|c|c|c|c|c|c|c|c|c|c|c|}
\hline Name of Bank & $\begin{array}{l}2007- \\
2008\end{array}$ & $\begin{array}{l}\text { Percentage of } \\
\text { Total Gross } \\
\text { NPA }\end{array}$ & Cumulative & Name of Bank & $\begin{array}{l}2008- \\
2009\end{array}$ & $\begin{array}{l}\text { Percentage of } \\
\text { Total Gross } \\
\text { NPA }\end{array}$ & Cumulative & Name of Bank & $\begin{array}{l}2009- \\
2010\end{array}$ & $\begin{array}{l}\text { Percentage } \\
\text { of Total } \\
\text { Gross NPA }\end{array}$ & Cumulative \\
\hline State Bank of India & $\mathrm{I} 28373$ & 33.95 & 33.95 & State Bank of India & I57I40 & 37.19 & 37.19 & State Bank of India & 195349 & 34.93 & 34.93 \\
\hline $\begin{array}{ll}\text { Punjab } & \text { National } \\
\text { Bank } & \end{array}$ & 33193 & 8.78 & 42.73 & Punjab National Bank & 25069 & 5.93 & 43.12 & Bank of India & 48827 & 8.73 & 43.66 \\
\hline $\begin{array}{l}\text { Central Bank of } \\
\text { India }\end{array}$ & 23500 & 6.22 & 48.94 & Bank of India & 24709 & 5.85 & 48.97 & $\begin{array}{l}\text { Indian Overseas } \\
\text { Bank }\end{array}$ & 36 III & 6.46 & 50.11 \\
\hline Bank of Baroda & I98I4 & 5.24 & 54.18 & Central Bank of India & 23160 & 5.48 & 54.45 & $\begin{array}{l}\text { Punjab National } \\
\text { Bank }\end{array}$ & $32 \mathrm{I} 44$ & 5.75 & 55.86 \\
\hline Bank of India & 19309 & $5 . \mathrm{II}$ & 59.29 & Canara Bank & 21680 & 5.13 & 59.58 & Union Bank of India & 26709 & 4.78 & 60.64 \\
\hline Syndicate Bank & 17687 & 4.68 & 63.97 & Indian Overseas Bank & 19234 & 4.55 & 64.13 & Canara Bank & 25903 & 4.63 & 65.27 \\
\hline Union Bank of India & 16566 & 4.38 & 68.35 & Union Bank of India & 19234 & 4.55 & 68.68 & $\begin{array}{l}\text { Central Bank of } \\
\text { India }\end{array}$ & 24580 & 4.39 & 69.66 \\
\hline UCO Bank & 16520 & 4.37 & 72.72 & Bank of Baroda & I8429 & 4.36 & 73.04 & Bank of Baroda & 24007 & 4.29 & 73.96 \\
\hline IDBI Bank & I5647 & 4.14 & 76.86 & Syndicate Bank & I5945 & 3.77 & 76.82 & IDBI Bank & $2 \mathrm{I} 294$ & $3.8 \mathrm{I}$ & 77.76 \\
\hline $\begin{array}{l}\text { Oriental Bank of } \\
\text { Commerce }\end{array}$ & I280I & 3.39 & 80.24 & UCO Bank & 15395 & 3.64 & 80.46 & Syndicate Bank & 20068 & 3.59 & 81.35 \\
\hline Canara Bank & $\mathrm{I} 2726$ & 3.37 & $83.6 \mathrm{I}$ & IDBI Bank & $\mathrm{I} 4357$ & 3.40 & 83.86 & UCO Bank & 16664 & 2.98 & 84.33 \\
\hline Allahabad Bank & I0I05 & 2.67 & 86.28 & Allahabad Bank & 10783 & 2.55 & $86.4 \mathrm{I}$ & $\begin{array}{l}\text { Oriental Bank of } \\
\text { Commerce }\end{array}$ & $\mathrm{I} 4688$ & 2.63 & 86.96 \\
\hline Indian Overseas Bank & 9970 & 2.64 & 88.92 & $\begin{array}{l}\text { Oriental Bank of } \\
\text { Commerce }\end{array}$ & I058I & 2.50 & 88.91 & $\begin{array}{l}\text { United Bank of } \\
\text { India }\end{array}$ & 13723 & 2.45 & $89.4 \mathrm{I}$ \\
\hline Bank of Maharashtra & 7663 & 2.03 & 90.94 & United Bank of India & 10200 & $2.4 \mathrm{I}$ & 91.33 & Allahabad Bank & I22I8 & 2.18 & 91.59 \\
\hline United Bank of India & 7610 & 2.01 & 92.96 & Bank of Maharashtra & 7984 & 1.89 & 93.22 & Bank of Maharashtra & $\mathrm{I} 2098$ & 2.16 & 93.76 \\
\hline Corporation Bank & 5844 & 1.55 & 94.50 & Vijaya Bank & 6988 & 1.65 & 94.87 & Vijaya Bank & 9945 & 1.78 & 95.54 \\
\hline Dena Bank & 5726 & I.5I & 96.02 & Dena Bank & 6208 & 1.47 & 96.34 & Corporation Bank & 6509 & I.I6 & 96.70 \\
\hline Vijaya Bank & $5 I I 5$ & 1.35 & 97.37 & Corporation Bank & 5592 & 1.32 & 97.66 & Dena Bank & 6420 & I.I5 & 97.85 \\
\hline Indian Bank & 4869 & 1.29 & 98.66 & Indian Bank & 4592 & 1.09 & 98.75 & Indian Bank & $5 \mathrm{IOI}$ & 0.91 & 98.76 \\
\hline Andhra Bank & 3724 & 0.98 & 99.64 & Andhra Bank & $368 \mathrm{I}$ & 0.87 & 99.62 & Andhra Bank & 4879 & 0.87 & 99.63 \\
\hline Punjab \& Sind Bank & 1355 & 0.36 & 100 & Punjab \& Sind Bank & 1610 & 0.38 & 100 & Punjab \& Sind Bank & 2062 & 0.37 & 100 \\
\hline TOTAL: & 378117 & 100 & & TOTAL: & $42257 \mathrm{I}$ & 100 & & TOTAL: & 559299 & 100 & \\
\hline
\end{tabular}




\begin{tabular}{|c|c|c|c|c|c|c|c|c|c|c|c|}
\hline Name of Bank & $\begin{array}{l}2010- \\
2011\end{array}$ & $\begin{array}{l}\text { Percentage } \\
\text { of Total } \\
\text { Gross } \\
\text { NPA }\end{array}$ & Cumulative & Name of Bank & $\begin{array}{l}2011- \\
2012\end{array}$ & $\begin{array}{l}\text { Percentage } \\
\text { of Total } \\
\text { Gross NPA }\end{array}$ & Cumulative & Name of Bank & $\begin{array}{l}2012- \\
2013\end{array}$ & $\begin{array}{l}\text { Percentage } \\
\text { of Total } \\
\text { Gross } \\
\text { NPA }\end{array}$ & Cumulative \\
\hline State Bank of India & 253263 & $36.4 \mathrm{I}$ & $36.4 \mathrm{I}$ & State Bank of India & 396765 & 36.48 & 36.48 & State Bank of India & 511894 & 33.49 & 33.49 \\
\hline Bank of India & 48116 & 6.92 & 43.33 & Punjab National Bank & 87196 & 8.02 & 44.50 & Punjab National Bank & I34658 & $8.8 \mathrm{I}$ & 42.29 \\
\hline Punjab National Bank & 43794 & 6.30 & 49.63 & Central Bank of India & 72730 & 6.69 & 51.19 & Bank of India & 87653 & 5.73 & 48.03 \\
\hline Union Bank of India & 36228 & $5.2 \mathrm{I}$ & 54.84 & Bank of India & 58940 & 5.42 & $56.6 \mathrm{I}$ & Central Bank of India & 84560 & 5.53 & 53.56 \\
\hline Bank of Baroda & 31525 & 4.53 & 59.37 & Union Bank of India & 54499 & 5.01 & 61.62 & Bank of Baroda & 79826 & 5.22 & $\overline{58.78}$ \\
\hline UCO Bank & 31504 & 4.53 & 63.90 & IDBI Bank & $455 \mathrm{I} 4$ & 4.19 & 65.80 & UCO Bank & 71301 & 4.66 & 63.44 \\
\hline Indian Overseas Bank & 30896 & 4.44 & 68.34 & Bank of Baroda & 44648 & $4 . \mathrm{II}$ & 69.91 & Indian Overseas Bank & 66080 & 4.32 & 67.77 \\
\hline Canara Bank & 30892 & 4.44 & 72.79 & UCO Bank & 40862 & 3.76 & 73.67 & IDBI Bank & 64500 & 4.22 & 71.99 \\
\hline IDBI Bank & 27847 & 4.00 & 76.79 & Canara Bank & 40318 & $3.7 \mathrm{I}$ & 77.37 & Union Bank of India & 63138 & 4.13 & 76.12 \\
\hline Syndicate Bank & 25990 & 3.74 & 80.53 & Indian Overseas Bank & 39201 & 3.60 & 80.98 & Canara Bank & 62602 & 4.10 & $80.2 \mathrm{I}$ \\
\hline Central Bank of India & 23940 & 3.44 & 83.97 & Oriental Bk of Comm. & 35805 & 3.29 & 84.27 & Allahabad Bank & 51370 & 3.36 & 83.57 \\
\hline 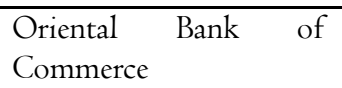 & 19205 & 2.76 & 86.73 & Syndicate Bank & 31827 & 2.93 & 87.20 & $\begin{array}{l}\begin{array}{l}\text { Oriental } \\
\text { Commerce }\end{array} \\
\text { Bank of }\end{array}$ & 41840 & 2.74 & 86.31 \\
\hline Allahabad Bank & 16479 & 2.37 & 89.10 & United Bank of India & 21764 & 2.00 & 89.20 & Andhra Bank & $37 I 45$ & 2.43 & 88.74 \\
\hline United Bank of India & 13558 & 1.95 & 91.05 & Allahabad Bank & 20890 & 1.92 & 91.12 & Indian Bank & 35655 & 2.33 & 91.07 \\
\hline Vijaya Bank & 12592 & $\mathrm{I} .8 \mathrm{I}$ & 92.86 & Indian Bank & 18508 & 1.70 & 92.82 & Syndicate Bank & 29785 & 1.95 & 93.02 \\
\hline Bank of Maharashtra & 11737 & 1.69 & 94.55 & Andhra Bank & 17980 & 1.65 & 94.47 & United Bank of India & 29638 & 1.94 & 94.96 \\
\hline Andhra Bank & 9956 & 1.43 & 95.98 & Vijaya Bank & 17185 & 1.58 & 96.05 & Corporation Bank & 20482 & 1.34 & 96.30 \\
\hline Dena Bank & 8422 & $\mathrm{I} .2 \mathrm{I}$ & 97.19 & Bank of Maharashtra & 12970 & I.19 & 97.25 & Punjab \& Sind Bank & 15369 & I.0I & 97.30 \\
\hline Corporation Bank & 7902 & I.I4 & 98.33 & Corporation Bank & 12742 & I.I7 & 98.42 & Vijaya Bank & I5329 & 1.00 & 98.31 \\
\hline Indian Bank & 7403 & 1.06 & 99.39 & Dena Bank & 9565 & 0.88 & 99.30 & Dena Bank & 14525 & 0.95 & 99.26 \\
\hline Punjab \& Sind Bank & 4243 & $0.6 \mathrm{I}$ & I00 & Punjab \& Sind Bank & 7634 & 0.70 & 100 & Bank of Maharashtra & II376 & 0.74 & 100 \\
\hline TOTAL: & 695492 & 100 & & TOTAL: & 1087543 & 100 & & TOTAL: & 1528726 & 100 & \\
\hline
\end{tabular}




\begin{tabular}{|c|c|c|c|c|c|c|c|c|c|c|c|}
\hline Name of Bank & $\begin{array}{l}2013- \\
2014\end{array}$ & $\begin{array}{l}\text { Percentage } \\
\text { of Total } \\
\text { Gross } \\
\text { NPA }\end{array}$ & Cumulative & Name of Bank & $\begin{array}{l}2014- \\
2015\end{array}$ & $\begin{array}{l}\text { Percentage } \\
\text { of Total } \\
\text { Gross } \\
\text { NPA }\end{array}$ & Cumulative & Name of Bank & $\begin{array}{l}2015- \\
2016\end{array}$ & $\begin{array}{l}\text { Percentage } \\
\text { of Total } \\
\text { Gross } \\
\text { NPA }\end{array}$ & Cumulative \\
\hline State Bank of India & 616054 & 29.47 & 29.47 & State Bank of India & 567253 & 22.26 & 22.26 & State Bank of India & 981728 & 19.02 & 19.02 \\
\hline Punjab National Bank & I8880I & 9.03 & 38.50 & Punjab National Bank & 256949 & I0.08 & 32.35 & Punjab National Bank & 558183 & I0.8I & 29.83 \\
\hline Bank of Baroda & II8759 & 5.68 & 44.18 & Bank of India & 221932 & $8.7 \mathrm{I}$ & 41.06 & Bank of India & 498791 & 9.66 & 39.50 \\
\hline Bank of India & I I8686 & 5.68 & 49.86 & Bank of Baroda & I626I4 & 6.38 & 47.44 & Bank of Baroda & 405210 & 7.85 & 47.35 \\
\hline Central Bank of India & I I5000 & 5.50 & 55.36 & Indian Overseas Bank & $\mathrm{I} 49225$ & 5.86 & 53.30 & Canara Bank & 316378 & 6.13 & 53.48 \\
\hline IDBI Bank & 99620 & 4.77 & 60.12 & Canara Bank & 130400 & 5.12 & 58.42 & Indian Overseas Bank & 300486 & 5.82 & 59.30 \\
\hline Union Bank of India & 95637 & 4.57 & 64.70 & Union Bank of India & 130309 & 5.11 & 63.53 & IDBI Bank & 248751 & 4.82 & 64.12 \\
\hline Indian Overseas Bank & 90205 & $4.3 \mathrm{I}$ & 69.01 & IDBI Bank & 126850 & 4.98 & $68.5 \mathrm{I}$ & Union Bank of India & 241709 & 4.68 & 68.80 \\
\hline Allahabad Bank & 80680 & 3.86 & 72.87 & Central Bank of India & II 8730 & 4.66 & 73.17 & Central Bank of India & 227210 & 4.40 & 73.20 \\
\hline Canara Bank & 75702 & 3.62 & 76.49 & UCO Bank & I0265I & 4.03 & 77.20 & UCO Bank & 209077 & 4.05 & 77.25 \\
\hline United Bank of India & $7 \mathrm{II} 80$ & 3.40 & 79.90 & Allahabad Bank & 83580 & 3.28 & 80.48 & Allahabad Bank & I53846 & 2.98 & 80.23 \\
\hline UCO Bank & 66214 & 3.17 & 83.07 & Corporation Bank & 71067 & 2.79 & 83.27 & $\begin{array}{lll}\text { Oriental Bank of } \\
\text { Commerce }\end{array}$ & I470I7 & 2.85 & 83.08 \\
\hline Andhra Bank & 58576 & 2.80 & 85.87 & Andhra Bank & 68765 & 2.70 & 85.97 & Corporation Bank & $\mathrm{I} 45443$ & 2.82 & 85.90 \\
\hline $\begin{array}{lll}\text { Oriental Bank } & \text { of } \\
\text { Commerce } & & \\
\end{array}$ & 56179 & 2.69 & 88.56 & United Bank of India & 65529 & 2.57 & 88.54 & Syndicate Bank & I38322 & 2.68 & 88.58 \\
\hline Corporation Bank & 47368 & 2.27 & 90.82 & Syndicate Bank & 64424 & 2.53 & 91.07 & Andhra Bank & I I 4436 & 2.22 & 90.80 \\
\hline Syndicate Bank & 46 I II & $2.2 \mathrm{I}$ & 93.03 & Bank of Maharashtra & $6402 I$ & $2.5 \mathrm{I}$ & 93.58 & Bank of Maharashtra & I03859 & $2.0 \mathrm{I}$ & 92.81 \\
\hline Indian Bank & 45622 & 2.18 & $95.2 \mathrm{I}$ & Indian Bank & 56704 & 2.23 & $95.8 \mathrm{I}$ & United Bank of India & 94710 & $\mathrm{I} .83$ & 94.64 \\
\hline Bank of Maharashtra & 28599 & $\mathrm{I} .37$ & 96.58 & Dena Bank & 43930 & 1.72 & 97.53 & Indian Bank & 88270 & $\mathrm{I} .7 \mathrm{I}$ & 96.35 \\
\hline Dena Bank & 26160 & 1.25 & 97.83 & Punjab \& Sind Bank & 30822 & $\mathrm{I} .2 \mathrm{I}$ & 98.74 & Dena Bank & 85605 & 1.66 & 98.01 \\
\hline Punjab \& Sind Bank & 25535 & 1.22 & 99.05 & Vijaya Bank & 24432 & 0.96 & 99.70 & Vijaya Bank & 60271 & I.17 & 99.18 \\
\hline Vijaya Bank & 19859 & 0.95 & $\mathrm{IOO}$ & $\begin{array}{ll}\text { Oriental } & \text { Bank } \\
\text { Commerce } & \end{array}$ & 7662 & 0.30 & $\mathrm{IOO}$ & Punjab \& Sind Bank & 42291 & 0.82 & 100 \\
\hline TOTAL: & 2090547 & 100 & & TOTAL: & 2547849 & 100 & & TOTAL: & 5161593 & 100 & \\
\hline
\end{tabular}




\begin{tabular}{|c|c|c|c|c|c|c|c|}
\hline Name of Bank & $\begin{array}{l}2016- \\
2017\end{array}$ & $\begin{array}{l}\text { Percentage } \\
\text { of Total } \\
\text { Gross } \\
\text { NPA }\end{array}$ & Cumulative & Name of Bank & $\begin{array}{l}2017- \\
2018\end{array}$ & $\begin{array}{l}\text { Percentage } \\
\text { of Total } \\
\text { Gross NPA }\end{array}$ & Cumulative \\
\hline State Bank of India & II 23430 & I8.I4 & 18.14 & State Bank of India & 2234275 & 24.95 & 24.95 \\
\hline Punjab National Bank & 553705 & 8.94 & 27.09 & Punjab National Bank & 866201 & 9.67 & 34.62 \\
\hline Bank of India & 520445 & 8.40 & 35.49 & Bank of India & 623285 & 6.96 & 41.58 \\
\hline IDBI Bank & 447526 & 7.23 & 42.72 & Bank of Baroda & 564804 & $6.3 \mathrm{I}$ & 47.88 \\
\hline Bank of Baroda & 427187 & 6.90 & 49.62 & IDBI Bank & 555883 & $6.2 \mathrm{I}$ & 54.09 \\
\hline Indian Overseas Bank & 350983 & 5.67 & 55.28 & Union Bank of India & 493699 & $5.5 \mathrm{I}$ & 59.60 \\
\hline Canara Bank & 342020 & 5.52 & $60.8 \mathrm{I}$ & Canara Bank & 474685 & 5.30 & 64.90 \\
\hline Union Bank of India & $337 \mathrm{I} 23$ & 5.44 & 66.25 & Indian Overseas Bank & 381802 & 4.26 & 69.17 \\
\hline Central Bank of India & 272510 & 4.40 & 70.65 & Central Bank of India & 381307 & 4.26 & 73.42 \\
\hline $\begin{array}{l}\text { Oriental Bank of } \\
\text { Commerce }\end{array}$ & 228593 & 3.69 & 74.35 & UCO Bank & 305499 & $3.4 \mathrm{I}$ & 76.84 \\
\hline UCO Bank & 225410 & 3.64 & 77.99 & Andhra Bank & $28 \mathrm{I} 244$ & 3.14 & 79.98 \\
\hline Allahabad Bank & 206878 & 3.34 & 81.33 & Allahabad Bank & 265628 & 2.97 & 82.94 \\
\hline Andhra Bank & 176700 & 2.85 & 84.18 & 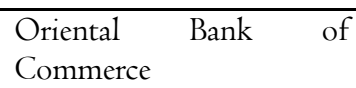 & 261336 & 2.92 & 85.86 \\
\hline Syndicate Bank & 176093 & 2.84 & 87.02 & Syndicate Bank & 257586 & 2.88 & 88.74 \\
\hline Bank of Maharashtra & 171887 & 2.78 & 89.80 & Corporation Bank & 222134 & 2.48 & 91.22 \\
\hline Corporation Bank & 170452 & 2.75 & 92.55 & Bank of Maharashtra & I84332 & 2.06 & 93.27 \\
\hline Dena Bank & 126187 & 2.04 & 94.59 & United Bank of India & I6552I & 1.85 & 95.12 \\
\hline United Bank of India & 109520 & 1.77 & 96.36 & Dena Bank & I636I4 & $\mathrm{I} .83$ & 96.95 \\
\hline Indian Bank & $9865 \mathrm{I}$ & 1.59 & 97.95 & Indian Bank & II990I & 1.34 & 98.29 \\
\hline Vijaya Bank & 63818 & 1.03 & 98.98 & Punjab \& Sind Bank & 78017 & 0.87 & 99.16 \\
\hline Punjab \& Sind Bank & 62976 & 1.02 & 100 & Vijaya Bank & 75261 & 0.84 & 100 \\
\hline TOTAL: & 6192094 & 100 & & TOTAL: & $89560 I 4$ & 100 & \\
\hline
\end{tabular}

Source: https://www.rbi.org.in and https://www.moneycontrol.com 
Appendix - B

ABC Analysis of Net Non-Performing Assets (NNPAs) or Loans of Select Indian Public Sector Banks for the period April 2007 to March 2018.

\begin{tabular}{|c|c|c|c|c|c|c|c|c|c|c|c|}
\hline Name of Bank & $\begin{array}{l}2007- \\
2009\end{array}$ & $\begin{array}{l}\text { Percentage } \\
\text { of total } \\
\text { Net NPA }\end{array}$ & Cumulative & Name of Bank & $\begin{array}{l}2008- \\
2009\end{array}$ & $\begin{array}{l}\text { Percentage } \\
\text { of total } \\
\text { Net NPA }\end{array}$ & Cumulative & Name of Bank & $\begin{array}{l}2009- \\
2010\end{array}$ & $\begin{array}{l}\text { Percentage } \\
\text { of total } \\
\text { Net NPA }\end{array}$ & Cumulative \\
\hline State Bank of India & 74243 & 44.32 & 44.32 & State Bank of India & 96774 & 48.47 & 48.47 & State Bank of India & 108702 & 39.27 & 39.27 \\
\hline UCO Bank & 10923 & 6.52 & 50.84 & Canara Bank & 15073 & 7.55 & 56.03 & Bank of India & 22075 & 7.97 & 47.24 \\
\hline IDBI Bank & I0829 & 6.46 & 57.30 & $\begin{array}{l}\text { Central Bank of } \\
\text { India }\end{array}$ & 10630 & 5.32 & 61.35 & $\begin{array}{ll}\text { Indian } & \text { Overseas } \\
\text { Bank } & \end{array}$ & 19950 & $7.2 \mathrm{I}$ & 54.45 \\
\hline Central Bank of India & I0600 & 6.33 & 63.63 & $\begin{array}{ll}\text { Indian } & \text { Overseas } \\
\text { Bank } & \\
\end{array}$ & 9991 & 5.00 & 66.35 & Canara Bank & 17997 & 6.50 & 60.95 \\
\hline Canara Bank & 8990 & 5.37 & 69.00 & IDBI Bank & 9490 & 4.75 & 7I.II & IDBI Bank & I4063 & 5.08 & 66.03 \\
\hline Punjab National Bank & 7538 & 4.50 & 73.50 & UCO Bank & 8127 & 4.07 & 75.18 & $\begin{array}{ll}\text { Punjab } & \text { National } \\
\text { Bank } & \\
\end{array}$ & 9817 & 3.55 & 69.57 \\
\hline Syndicate Bank & 6227 & 3.72 & 77.22 & Syndicate Bank & 6318 & 3.16 & 78.34 & UCO Bank & 9663 & 3.49 & 73.06 \\
\hline Bank of India & 5920 & 3.53 & 80.75 & Bank of India & 6282 & 3.15 & 81.49 & Union Bank of India & 9653 & 3.49 & 76.55 \\
\hline $\begin{array}{l}\text { Oriental Bank of } \\
\text { Commerce }\end{array}$ & 5384 & $3.2 \mathrm{I}$ & 83.96 & $\begin{array}{l}\text { United Bank of } \\
\text { India }\end{array}$ & 5250 & 2.63 & 84.12 & Syndicate Bank & 9632 & 3.48 & 80.03 \\
\hline Bank of Baroda & 4936 & 2.95 & $86.9 \mathrm{I}$ & Bank of Baroda & 4490 & 2.25 & 86.37 & United Bank of India & 7786 & $2.8 \mathrm{I}$ & 82.84 \\
\hline Allahabad Bank & 3998 & 2.39 & 89.30 & $\begin{array}{l}\text { Oriental Bank of } \\
\text { Commerce }\end{array}$ & 4424 & 2.22 & 88.59 & $\begin{array}{l}\text { Central Bank of } \\
\text { India }\end{array}$ & 7270 & 2.63 & 85.47 \\
\hline Indian Overseas Bank & 3632 & 2.17 & 91.46 & Allahabad Bank & $422 \mathrm{I}$ & $2.1 \mathrm{I}$ & 90.70 & $\begin{array}{l}\text { Oriental Bank of } \\
\text { Commerce }\end{array}$ & 7238 & $2.6 \mathrm{I}$ & 88.08 \\
\hline United Bank of India & 3060 & 1.83 & 93.29 & Union Bank of India & 3259 & 1.63 & 92.33 & Bank of Maharashtra & 6624 & 2.39 & 90.48 \\
\hline Bank of Maharashtra & 2540 & 1.52 & 94.81 & Dena Bank & $3 I 34$ & 1.57 & 93.90 & Bank of Baroda & 6023 & 2.18 & 92.65 \\
\hline Dena Bank & $2 \mathrm{I} 54$ & 1.29 & 96.09 & Vijaya Bank & 2923 & $\mathrm{I} .46$ & 95.37 & Vijaya Bank & 5818 & 2.10 & 94.75 \\
\hline Vijaya Bank & I8I6 & $\mathrm{I} .08$ & 97.18 & Bank of Maharashtra & 2719 & $\mathrm{I} .36$ & 96.73 & Allahabad Bank & 4702 & 1.70 & 96.45 \\
\hline Union Bank of India & 1276 & 0.76 & 97.94 & $\begin{array}{ll}\text { Punjab National } \\
\text { Bank }\end{array}$ & 2639 & 1.32 & 98.05 & Dena Bank & 4275 & 1.54 & 98.00 \\
\hline Corporation Bank & 1269 & 0.76 & 98.70 & Corporation Bank & 1383 & 0.69 & 98.74 & Corporation Bank & 1973 & $0.7 \mathrm{I}$ & $98.7 \mathrm{I}$ \\
\hline Indian Bank & 976 & 0.58 & 99.28 & Indian Bank & 938 & 0.47 & 99.21 & Indian Bank & $\mathrm{I} 449$ & 0.52 & 99.23 \\
\hline Punjab \& Sind Bank & 670 & 0.40 & 99.68 & Andhra Bank & 792 & 0.40 & $99.6 \mathrm{I}$ & Punjab \& Sind Bank & II66 & 0.42 & 99.65 \\
\hline Andhra Bank & 537 & 0.32 & 100 & Punjab \& Sind Bank & 780 & 0.39 & 100 & Andhra Bank & 957 & 0.35 & 100 \\
\hline TOTAL: & $\mathrm{I} 675 \mathrm{I} 8$ & 100 & & TOTAL: & I99637 & 100 & & TOTAL: & 276833 & 100 & \\
\hline
\end{tabular}




\begin{tabular}{|c|c|c|c|c|c|c|c|c|c|c|c|}
\hline Name of Bank & $\begin{array}{r}2010- \\
2011\end{array}$ & $\begin{array}{r}\text { Percentage } \\
\text { of total } \\
\text { Net NPA }\end{array}$ & Cumulative & Name of Bank & $\begin{array}{r}2011- \\
2012\end{array}$ & $\begin{array}{r}\text { Percentage } \\
\text { of total } \\
\text { Net NPA }\end{array}$ & Cumulative & Name of Bank & $\begin{array}{r}2012- \\
2013\end{array}$ & $\begin{array}{r}\text { Percentage } \\
\text { of total } \\
\text { Net NPA }\end{array}$ & Cumulative \\
\hline State Bank of India & 123469 & 36.73 & 36.73 & State Bank of India & I58I89 & 28.87 & 28.87 & State Bank of India & 219565 & 26.20 & 26.20 \\
\hline Canara Bank & 23299 & 6.93 & 43.67 & $\begin{array}{l}\text { Central Bank of } \\
\text { India }\end{array}$ & 46000 & 8.40 & 37.27 & $\begin{array}{ll}\text { Punjab } & \text { National } \\
\text { Bank } & \end{array}$ & 72365 & 8.63 & 34.83 \\
\hline Punjab National Bank & 20386 & 6.07 & 49.73 & $\begin{array}{ll}\text { Punjab National } \\
\text { Bank }\end{array}$ & 44542 & 8.13 & 45.40 & Bank of India & 59473 & 7.10 & 41.93 \\
\hline Bank of India & 19450 & 5.79 & 55.52 & Bank of India & 36564 & 6.67 & 52.07 & Canara Bank & $5278 \mathrm{I}$ & 6.30 & 48.23 \\
\hline UCO Bank & 18246 & 5.43 & 60.95 & Canara Bank & 33863 & 6.18 & 58.25 & $\begin{array}{l}\text { Central Bank of } \\
\text { India }\end{array}$ & 49880 & 5.95 & 54.18 \\
\hline Union Bank of India & 18034 & 5.37 & $66.3 \mathrm{I}$ & Union Bank of India & 30250 & 5.52 & 63.78 & Bank of Baroda & 41920 & 5.00 & 59.18 \\
\hline IDBI Bank & 16779 & 4.99 & $7 \mathrm{I} .3 \mathrm{I}$ & IDBI Bank & 29109 & 5.31 & 69.09 & Allahabad Bank & $4 \mathrm{I} 268$ & 4.92 & 64.11 \\
\hline Indian Overseas Bank & $\mathrm{I} 3284$ & 3.95 & 75.26 & $\begin{array}{l}\text { Oriental Bank of } \\
\text { Commerce }\end{array}$ & 24590 & 4.49 & 73.58 & UCO Bank & 40693 & 4.86 & 68.96 \\
\hline Syndicate Bank & 10308 & 3.07 & 78.32 & UCO Bank & 22639 & 4.13 & $77.7 \mathrm{I}$ & $\begin{array}{ll}\text { Indian } & \text { Overseas } \\
\text { Bank } & \\
\end{array}$ & 40272 & $4.8 \mathrm{I}$ & 73.77 \\
\hline $\begin{array}{l}\text { Oriental Bank of } \\
\text { Commerce }\end{array}$ & 9382 & 2.79 & 81.12 & $\begin{array}{l}\text { Indian } \quad \text { Overseas } \\
\text { Bank }\end{array}$ & 19074 & 3.48 & 81.19 & Union Bank of India & 33534 & 4.00 & 77.77 \\
\hline Central Bank of India & 8470 & 2.52 & 83.64 & Bank of Baroda & 15436 & 2.82 & 84.01 & IDBI Bank & 31004 & 3.70 & 81.47 \\
\hline Bank of Baroda & 7909 & 2.35 & 85.99 & Indian Bank & II968 & 2.18 & 86.19 & $\begin{array}{l}\text { Oriental Bank of } \\
\text { Commerce }\end{array}$ & 29027 & 3.46 & 84.93 \\
\hline United Bank of India & 7574 & 2.25 & 88.24 & Syndicate Bank & II 854 & 2.16 & 88.36 & Andhra Bank & 24092 & 2.87 & $87.8 \mathrm{I}$ \\
\hline Vijaya Bank & 7412 & $2.2 \mathrm{I}$ & 90.45 & Allahabad Bank & I09I7 & 1.99 & 90.35 & Indian Bank & 23843 & 2.84 & 90.65 \\
\hline Allahabad Bank & 7364 & 2.19 & 92.64 & $\begin{array}{l}\text { United Bank of } \\
\text { India }\end{array}$ & 10756 & 1.96 & $92.3 \mathrm{I}$ & United Bank of India & 19700 & 2.35 & 93.00 \\
\hline Bank of Maharashtra & 6190 & $\mathrm{I} .84$ & 94.48 & Vijaya Bank & 9980 & 1.82 & 94.13 & Corporation Bank & I4I09 & 1.68 & 94.68 \\
\hline Dena Bank & 5490 & I.63 & $96.1 \mathrm{I}$ & Corporation Bank & 8694 & 1.59 & 95.72 & Syndicate Bank & II248 & 1.34 & 96.03 \\
\hline Corporation Bank & 3977 & I.I8 & 97.30 & Andhra Bank & 7559 & 1.38 & 97.10 & Punjab \& Sind Bank & III04 & 1.32 & 97.35 \\
\hline Indian Bank & 3970 & I.I8 & 98.48 & Dena Bank & 5717 & 1.04 & 98.14 & Dena Bank & 9172 & I.09 & 98.45 \\
\hline Andhra Bank & 2737 & $0.8 \mathrm{I}$ & 99.29 & Punjab \& Sind Bank & 5476 & 1.00 & 99.14 & Vijaya Bank & 9097 & 1.09 & 99.53 \\
\hline Punjab \& Sind Bank & 2379 & $0.7 \mathrm{I}$ & 100 & Bank of Maharashtra & 4696 & 0.86 & 100 & Bank of Maharashtra & 3929 & 0.47 & IOO \\
\hline TOTAL: & 336109 & 100 & & TOTAL: & 547873 & 100 & & TOTAL: & 838076 & 100 & \\
\hline
\end{tabular}




\begin{tabular}{|c|c|c|c|c|c|c|c|c|c|c|c|}
\hline Name of Bank & $\begin{array}{r}2013- \\
2014\end{array}$ & $\begin{array}{r}\text { Percentage } \\
\text { of total } \\
\text { Net NPA } \\
\end{array}$ & Cumulative & Name of Bank & $\begin{array}{r}2014- \\
2015\end{array}$ & $\begin{array}{r}\text { Percentage } \\
\text { of total } \\
\text { Net NPA } \\
\end{array}$ & Cumulative & Name of Bank & $\begin{array}{r}2015- \\
2016\end{array}$ & $\begin{array}{r}\text { Percentage } \\
\text { of total } \\
\text { Net NPA } \\
\end{array}$ & Cumulative \\
\hline State Bank of India & $31096 \mathrm{I}$ & 25.99 & 25.99 & State Bank of India & 275906 & 18.36 & 18.36 & State Bank of India & 558070 & 18.16 & 18.16 \\
\hline Punjab National Bank & 99170 & 8.29 & 34.28 & $\begin{array}{l}\text { Punjab National } \\
\text { Bank }\end{array}$ & 153965 & 10.25 & 28.61 & Punjab National Bank & 354226 & II.53 & 29.69 \\
\hline Bank of India & 74172 & 6.20 & 40.48 & Bank of India & 135176 & 9.00 & 37.60 & Bank of India & 279964 & $9.1 \mathrm{I}$ & 38.80 \\
\hline Central Bank of India & 66500 & 5.56 & 46.04 & $\begin{array}{l}\text { Indian } \\
\text { Bank }\end{array}$ & 98133 & 6.53 & 44.13 & Canara Bank & 208329 & 6.78 & 45.58 \\
\hline Bank of Baroda & 60348 & 5.04 & 51.08 & Canara Bank & $8740 \mathrm{I}$ & 5.82 & 49.95 & Bank of Baroda & 194065 & 6.32 & 51.89 \\
\hline Canara Bank & 59655 & 4.99 & 56.07 & Bank of Baroda & 80695 & 5.37 & 55.32 & Indian Overseas Bank & 192126 & 6.25 & 58.15 \\
\hline Allahabad Bank & 57218 & 4.78 & 60.85 & $\begin{array}{l}\text { Union } \\
\text { India }\end{array}$ & 69190 & 4.60 & 59.93 & IDBI Bank & I46434 & 4.77 & 62.91 \\
\hline Indian Overseas Bank & $5658 \mathrm{I}$ & 4.73 & 65.58 & $\begin{array}{l}\text { Central Bank of } \\
\text { India }\end{array}$ & 68070 & 4.53 & 64.46 & Union Bank of India & I40259 & 4.56 & 67.48 \\
\hline Union Bank of India & 53403 & 4.46 & 70.04 & UCO Bank & 63306 & $4.2 \mathrm{I}$ & 68.67 & Central Bank of India & $\mathrm{I} 32420$ & $4.3 \mathrm{I}$ & 71.79 \\
\hline IDBI Bank & 49023 & 4.10 & 74.14 & IDBI Bank & 59925 & 3.99 & 72.66 & UCO Bank & II 4436 & 3.72 & $75.5 \mathrm{I}$ \\
\hline United Bank of India & $4664 \mathrm{I}$ & 3.90 & 78.04 & Allahabad Bank & 59789 & 3.98 & 76.64 & Allahabad Bank & 102925 & 3.35 & 78.86 \\
\hline $\begin{array}{l}\text { Oriental Bank of } \\
\text { Commerce }\end{array}$ & 39044 & 3.26 & 81.30 & $\begin{array}{l}\text { Oriental Bank of } \\
\text { Commerce }\end{array}$ & 48162 & $3.2 \mathrm{I}$ & 79.84 & $\begin{array}{l}\text { Oriental Bank of } \\
\text { Commerce }\end{array}$ & 99322 & 3.23 & 82.09 \\
\hline UCO Bank & 35564 & 2.97 & 84.27 & Corporation Bank & 44650 & 2.97 & 82.81 & Corporation Bank & 91601 & 2.98 & 85.07 \\
\hline Andhra Bank & 33425 & 2.79 & 87.07 & $\begin{array}{l}\text { Bank of } \\
\text { Maharashtra }\end{array}$ & $4 \mathrm{I} 266$ & 2.75 & 85.56 & Syndicate Bank & 90149 & 2.93 & 88.01 \\
\hline Corporation Bank & 31806 & 2.66 & 89.73 & $\begin{array}{l}\text { United Bank of } \\
\text { India }\end{array}$ & $408 \mathrm{I} 4$ & 2.72 & 88.27 & Bank of Maharashtra & 68320 & 2.22 & 90.23 \\
\hline Indian Bank & 27637 & $2.3 \mathrm{I}$ & 92.04 & Syndicate Bank & 38437 & 2.56 & 90.83 & United Bank of India & 61107 & 1.99 & 92.22 \\
\hline Syndicate Bank & 27206 & 2.27 & 94.31 & Andhra Bank & 36886 & 2.45 & 93.29 & Andhra Bank & 60357 & 1.96 & 94.18 \\
\hline Punjab \& Sind Bank & 19186 & 1.60 & 95.91 & Indian Bank & 31470 & 2.09 & 95.38 & Indian Bank & 54194 & 1.76 & 95.95 \\
\hline Dena Bank & 18189 & 1.52 & 97.43 & Dena Bank & 30143 & 2.01 & 97.39 & Dena Bank & 52305 & 1.70 & 97.65 \\
\hline Bank of Maharashtra & 18073 & $\mathrm{I} .5 \mathrm{I}$ & 98.94 & Punjab \& Sind Bank & 22660 & $\mathrm{I} .5 \mathrm{I}$ & 98.90 & Vijaya Bank & 42768 & 1.39 & 99.04 \\
\hline Vijaya Bank & $\mathrm{I} 2624$ & 1.06 & 100 & Vijaya Bank & 16597 & I.IO & 100 & Punjab \& Sind Bank & 29495 & 0.96 & 100 \\
\hline TOTAL: & II96426 & 100 & & TOTAL: & I50264I & 100 & & TOTAL: & 3072872 & 100 & \\
\hline
\end{tabular}




\begin{tabular}{|c|c|c|c|c|c|c|c|}
\hline Name of Bank & 2016-I7 & $\begin{array}{l}\text { Percentage } \\
\text { of total } \\
\text { Net NPA }\end{array}$ & Cumulative & Name of Bank & 2017-I8 & $\begin{array}{l}\text { Percentage } \\
\text { of total } \\
\text { Net NPA }\end{array}$ & Cumulative \\
\hline State Bank of India & 582774 & 16.92 & 16.92 & State Bank of India & II08547 & 24.39 & 24.39 \\
\hline Punjab National Bank & $32702 \mathrm{I}$ & 9.50 & 26.42 & Punjab National Bank & 486843 & I0.7I & 35.10 \\
\hline Bank of India & 253050 & 7.35 & 33.77 & IDBI Bank & $28665 \mathrm{I}$ & $6.3 \mathrm{I}$ & $\overline{41.4 \mathrm{I}}$ \\
\hline IDBI Bank & 252058 & 7.32 & 41.08 & Canara Bank & 285424 & 6.28 & 47.69 \\
\hline Canara Bank & 216490 & 6.29 & 47.37 & Bank of India & 282073 & $6.2 \mathrm{I}$ & 53.90 \\
\hline Indian Overseas Bank & 197493 & 5.73 & $53.1 \mathrm{I}$ & Union Bank of India & 243263 & 5.35 & 59.25 \\
\hline Union Bank of India & I8832I & 5.47 & 58.57 & Bank of Baroda & 234827 & 5.17 & 64.42 \\
\hline Bank of Baroda & 180802 & 5.25 & 63.82 & Indian Overseas Bank & 203997 & 4.49 & $68.9 \mathrm{I}$ \\
\hline Central Bank of India & 142180 & 4.13 & 67.95 & Central Bank of India & 173779 & 3.82 & 72.73 \\
\hline 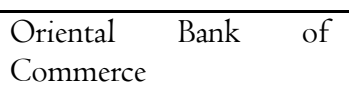 & I4II78 & 4.10 & 72.05 & $\begin{array}{lll}\begin{array}{l}\text { Oriental } \\
\text { Commerce }\end{array} & \text { Bank }\end{array}$ & I42829 & 3.14 & 75.87 \\
\hline Allahabad Bank & I34335 & 3.90 & 75.95 & UCO Bank & I4082 I & 3.10 & 78.97 \\
\hline Corporation Bank & 116922 & 3.40 & 79.35 & Corporation Bank & $\mathrm{I} 40770$ & 3.10 & 82.07 \\
\hline Bank of Maharashtra & II2296 & 3.26 & $82.6 \mathrm{I}$ & Syndicate Bank & 132395 & $2.9 \mathrm{I}$ & 84.98 \\
\hline UCO Bank & 107034 & $3 . \mathrm{II}$ & 85.72 & Andhra Bank & 126369 & 2.78 & 87.76 \\
\hline Syndicate Bank & I04IIO & 3.02 & 88.74 & Allahabad Bank & I2229I & 2.69 & 90.45 \\
\hline Andhra Bank & 103548 & 3.01 & 91.75 & United Bank of India & 103163 & 2.27 & 92.72 \\
\hline Dena Bank & $7735 \mathrm{I}$ & 2.25 & 93.99 & Bank of Maharashtra & $964 \mathrm{I} 2$ & 2.12 & 94.85 \\
\hline United Bank of India & 65919 & I.9I & $95.9 \mathrm{I}$ & Dena Bank & 78388 & 1.72 & 96.57 \\
\hline Indian Bank & 56066 & 1.63 & 97.53 & Indian Bank & 59596 & I.3I & 97.88 \\
\hline Punjab \& Sind Bank & $4375 \mathrm{I}$ & 1.27 & 98.80 & Vijaya Bank & 50212 & I.I0 & 98.99 \\
\hline Vijaya Bank & 41182 & 1.20 & 100 & Punjab \& Sind Bank & 46079 & I.OI & 100 \\
\hline TOTAL: & $344388 \mathrm{I}$ & 100 & & TOTAL: & 4544729 & 100.00 & \\
\hline
\end{tabular}

Source: https://www.rbi.org.in and https://www.moneycontrol.com 


\section{Appendix - C}

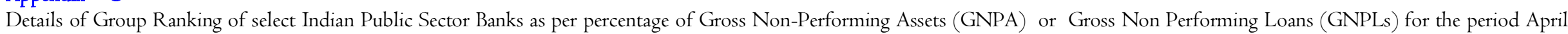

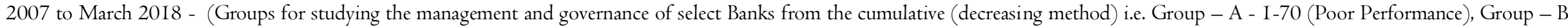
- 7I-90 (Satisfactory Performance) and Group - C - 9I-I00 (Good Performance).

\begin{tabular}{|c|c|c|}
\hline & Group & $2007-2008$ \\
\hline Highest GNPAs & A (I-70\%) (Poor Performance) & $\begin{array}{l}\text { State Bank of India, Punjab National Bank, Central Bank of India, Bank of Baroda, Bank of India, Syndicate } \\
\text { Bank, Canara Bank. }\end{array}$ \\
\hline Medium GNPAs & B (7I-90\%) (Satisfactory Performance) & $\begin{array}{l}\text { UCO Bank, IDBI Bank, Oriental Bank of Commerce, Allahabad Bank, Indian Overseas Bank, Bank of } \\
\text { Maharashtra. }\end{array}$ \\
\hline \multirow[t]{2}{*}{ Lowest GNPAs } & C (9I-I00\%) (Good Performance) & $\begin{array}{l}\text { United Bank of India, Corporation Bank, Dena Bank, Vijaya Bank, Indian Bank, Andhra Bank, Punjab \& Sind } \\
\text { Bank. }\end{array}$ \\
\hline & Group & $2008-2009$ \\
\hline Highest GNPAs & A (I-70\%) (Poor Performance) & $\begin{array}{l}\text { State Bank of India, Punjab National Bank, Bank of India, Central Bank of India, Canara Bank, Indian Overseas } \\
\text { Bank, Union Bank of India. }\end{array}$ \\
\hline Medium GNPAs & B (7I-90\%) (Satisfactory Performance) & Bank of Baroda, Syndicate Bank, UCO Bank, IDBI Bank, Allahabad Bank, Oriental Bank of Commerce. \\
\hline \multirow[t]{2}{*}{ Lowest GNPAs } & C (9I-I00\%) (Good Performance) & $\begin{array}{l}\text { United Bank of India, Bank of Maharashtra, Vijaya Bank, Dena Bank, Corporation Bank, Indian Bank, Andhra } \\
\text { Bank, Punjab \& Sind Bank. }\end{array}$ \\
\hline & Group & $2009-2010$ \\
\hline Highest GNPAs & A (I-70\%) (Poor Performance) & $\begin{array}{l}\text { State Bank of India, Bank of India, Indian Overseas Bank, Punjab National Bank, Canara Bank, Central Bank of } \\
\text { India. }\end{array}$ \\
\hline Medium GNPAs & B (7I-90\%) (Satisfactory Performance) & $\begin{array}{l}\text { Bank of Baroda, IDBI Bank, Syndicate Bank, UCO Bank, Union Bank of India, Oriental Bank of Commerce, } \\
\text { United Bank of India. }\end{array}$ \\
\hline \multirow[t]{2}{*}{ Lowest GNPAs } & C (9I-I00\%) (Good Performance) & $\begin{array}{l}\text { Allahabad Bank, Bank of Maharashtra, Vijaya Bank, Corporation Bank, Dena Bank, Indian Bank, Andhra Bank, } \\
\text { Punjab \& Sind Bank. }\end{array}$ \\
\hline & Group & 20I0-20II \\
\hline Highest GNPAs & A (I-70\%) (Poor Performance) & $\begin{array}{l}\text { State Bank of India, Bank of India, Punjab National Bank, Union Bank of India, Bank of Baroda, UCO Bank, } \\
\text { Indian Overseas Bank. }\end{array}$ \\
\hline Medium GNPAs & B (7I-90\%) (Satisfactory Performance) & Canara Bank, IDBI Bank, Central Bank of India, Oriental Bank of Commerce, Allahabad Bank. \\
\hline \multirow[t]{2}{*}{ Lowest GNPAs } & C (9I-I00\%) (Good Performance) & $\begin{array}{l}\text { United Bank of India, Vijaya Bank, Bank of Maharashtra, Andhra Bank, Dena Bank, Corporation Bank, Indian } \\
\text { Bank, Punjab \& Sind Bank. }\end{array}$ \\
\hline & Group & 20II-20I2 \\
\hline Highest GNPAs & A (I-70\%) (Poor Performance) & State Bank of India, Punjab National Bank, Central Bank of India, Bank of India, Union Bank of India, IDBI \\
\hline
\end{tabular}


Bank, Bank of Baroda.

\begin{tabular}{|c|c|c|}
\hline & & Bank, Bank of Baroda. \\
\hline Medium GNPAs & B (7I-90\%) (Satisfactory Performance) & UCO Bank, Canara Bank, Indian Overseas Bank, Syndicate Bank, United Bank of India. \\
\hline \multirow[t]{2}{*}{ Lowest GNPAs } & C (9I-I00\%) (Good Performance) & $\begin{array}{l}\text { Allahabad Bank, Indian Bank, Andhra Bank, Vijaya Bank, Bank of Maharashtra, Corporation Bank, Dena } \\
\text { Bank, Punjab \& Sind Bank. }\end{array}$ \\
\hline & Group & $2012-2013$ \\
\hline Highest GNPAs & A (I-70\%) (Poor Performance) & $\begin{array}{l}\text { State Bank of India, Punjab National Bank, Bank of India, Central Bank of India, Bank of Baroda, UCO Bank, } \\
\text { Indian Overseas Bank. }\end{array}$ \\
\hline Medium GNPAs & B (7I-90\%)(Satisfactory Performance) & IDBI Bank, Union Bank of India, Canara Bank, Allahabad Bank, Oriental Bank of Commerce, Andhra Bank. \\
\hline \multirow[t]{2}{*}{ Lowest GNPAs } & C (9I-I00\%) (Good Performance) & $\begin{array}{l}\text { Indian Bank, Syndicate Bank, United Bank of India, Corporation Bank, Punjab \& Sind Bank, Vijaya Bank, } \\
\text { Dena Bank, Bank of Maharashtra. }\end{array}$ \\
\hline & Group & 20I3-20I4 \\
\hline Highest GNPAs & A (I-70\%) (Poor Performance) & $\begin{array}{l}\text { State Bank of India, Punjab National Bank, Bank of Baroda, Bank of India, Central Bank of India, IDBI Bank, } \\
\text { Union Bank of India, Indian Overseas Bank. }\end{array}$ \\
\hline Medium GNPAs & B (7I-90\%) (Satisfactory Performance) & $\begin{array}{l}\text { Allahabad Bank, Canara Bank, United Bank of India, UCO Bank, Andhra Bank, Oriental Bank of Commerce, } \\
\text { Corporation Bank. }\end{array}$ \\
\hline \multirow[t]{2}{*}{ Lowest GNPAs } & C (9I-I00\%) (Good Performance) & Syndicate, Indian, BOM, Dena, P\&SB, Vijaya \\
\hline & Group & 2014-2015 \\
\hline Highest GNPAs & A (I-70\%) (Poor Performance) & $\begin{array}{l}\text { State Bank of India, Punjab National Bank, Bank of India, Bank of Baroda, Indian Overseas Bank, Canara } \\
\text { Bank, Union Bank of India, IDBI Bank. }\end{array}$ \\
\hline Medium GNPAs & B (7I-90\%) (Satisfactory Performance) & Central Bank of India, UCO Bank, Allahabad Bank, Corporation Bank, Andhra Bank, United Bank of India. \\
\hline \multirow[t]{2}{*}{ Lowest GNPAs } & C (9I-I00\%) (Good Performance) & $\begin{array}{l}\text { Syndicate Bank, Bank of Maharashtra, Indian Bank, Dena Bank, Punjab \& Sind Bank, Oriental Bank of } \\
\text { Commerce, Vijaya Bank. }\end{array}$ \\
\hline & Group & $2015-2016$ \\
\hline Highest GNPAs & A (I-70\%) (Poor Performance) & $\begin{array}{l}\text { State Bank of India, Punjab National Bank, Bank of India, Bank of Baroda, Canara Bank, Indian Overseas } \\
\text { Bank, IDBI Bank, Union Bank of India. }\end{array}$ \\
\hline Medium GNPAs & B (7I-90\%) (Satisfactory Performance) & $\begin{array}{l}\text { Central Bank of India, UCO Bank, Allahabad Bank, Oriental Bank of Commerce, Corporation Bank, Syndicate } \\
\text { Bank, Andhra Bank. }\end{array}$ \\
\hline \multirow[t]{2}{*}{ Lowest GNPAs } & C (9I-I00\%) (Good Performance) & Bank of Maharashtra, United Bank of India, Indian Bank, Dena Bank, Vijaya Bank, Punjab \& Sind Bank. \\
\hline & Group & $2016-2017$ \\
\hline Highest GNPAs & A (I-70\%) (Poor Performance) & $\begin{array}{l}\text { State Bank of India, Punjab National Bank, Bank of India, Indian Overseas Bank, Canara Bank, Union Bank of } \\
\text { India, Central Bank of India. }\end{array}$ \\
\hline Medium GNPAs & B (7I-90\%) (Satisfactory Performance) & $\begin{array}{l}\text { Oriental Bank of Commerce, UCO Bank, Allahabad Bank, Andhra Bank, Syndicate Bank, Bank of } \\
\text { Marastra }\end{array}$ \\
\hline
\end{tabular}




\begin{tabular}{|c|c|c|}
\hline Lowest GNPAs & C (9I-I00\%) (Good Performance) & Corporation Bank, Dena Bank, United Bank of India, Indian Bank, Vijaya Bank, Punjab \& Sind Bank. \\
\hline & Group & $2017-2018$ \\
\hline Highest GNPAs & A (I-70\%) (Poor Performance) & $\begin{array}{l}\text { State Bank of India, Punjab National Bank, Bank of India, Bank of Baroda, IDBI Bank, Union Bank of India, } \\
\text { Canara Bank and Indian Overseas Bank. }\end{array}$ \\
\hline Medium GNPAs & B (7I-90\%) (Satisfactory Performance) & $\begin{array}{l}\text { Central Bank of India, UCO Bank, Andhra Bank, Allahabad Bank, Oriental Bank of Commerce, Syndicate } \\
\text { Bank. }\end{array}$ \\
\hline Lowest GNPAs & C (9I-I00\%) (Good Performance) & Corporation Bank, Bank of Maharashtra, Dena Bank, Indian Bank, Punjab \& Sind Bank, Vijaya Bank. \\
\hline
\end{tabular}

Appendix - D

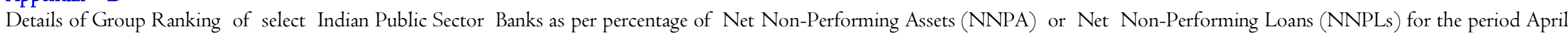

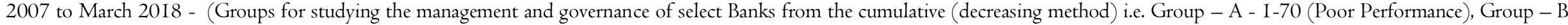
- 7I-90 (Satisfactory Performance) and Group - C - 9I-I00 (Good Performance).

\begin{tabular}{|c|c|c|}
\hline & Group & $2007-2008$ \\
\hline Highest NNPAs & A (I-70\%) (Poor Performance) & State Bank of India, UCO Bank, IDBI Bank, Central Bank of India, Canara Bank. \\
\hline Medium NNPAs & B (7I-90\%) (Satisfactory Performance) & $\begin{array}{l}\text { Punjab National Bank, Syndicate Bank, Bank of India, Oriental Bank of Commerce, Bank of Baroda, Allahabad } \\
\text { Bank. }\end{array}$ \\
\hline Lowest NNPAs & C (9I-I00\%) (Good Performance) & $\begin{array}{l}\text { Indian Overseas Bank, United Bank of India, Bank of Maharashtra, Dena Bank, Vijaya Bank, Union Bank of } \\
\text { India, Corporation Bank, Indian Bank, Punjab \& Sind Bank, Andhra Bank. }\end{array}$ \\
\hline & Group & $2008-2009$ \\
\hline Highest NNPAs & A (I-70\%) (Poor Performance) & State Bank of India, Canara Bank, Central Bank of India, Indian Overseas Bank. \\
\hline Medium NNPAs & B (7I-90\%) (Satisfactory Performance) & $\begin{array}{l}\text { IDBI Bank, UCO Bank, Syndicate Bank, Bank of India, United Bank of India, Bank of Baroda, Oriental Bank } \\
\text { of Commerce, Allahabad Bank. }\end{array}$ \\
\hline Lowest NNPAs & C (9I-I00\%) (Good Performance) & $\begin{array}{l}\text { Union Bank of India, Dena Bank, Vijaya Bank, Bank of Maharashtra, Punjab National Bank, Corporation } \\
\text { Bank, Indian Bank, Andhra Bank, Punjab \& Sind Bank. }\end{array}$ \\
\hline & Group & $2009-2010$ \\
\hline Highest NNPAs & A (I-70\%) (Poor Performance) & State Bank of India, Bank of India, Indian Overseas Bank, Canara Bank, IDBI Bank, Punjab National Bank. \\
\hline Medium NNPAs & B (7I-90\%) (Satisfactory Performance) & $\begin{array}{l}\text { UCO Bank, Union Bank of India, Syndicate Bank, United Bank of India, Central Bank of India, Oriental Bank } \\
\text { of Commerce, Bank of Maharashtra. }\end{array}$ \\
\hline Lowest NNPAs & C (9I-I00\%) (Good Performance) & $\begin{array}{l}\text { Bank of Baroda, Vijaya Bank, Allahabad Bank, Dena bank, Corporation Bank, Indian Bank, Punjab \& Sind } \\
\text { Bank, Andhra Bank. }\end{array}$ \\
\hline & Group & 20I0-20II \\
\hline Highest NNPAs & A (I-70\%) (Poor Performance) & State Bank of India, Canara Bank, Punjab National Bank, Bank of India, Bank of India, UCO Bank, Union \\
\hline
\end{tabular}




\begin{tabular}{|c|c|c|}
\hline & & Bank. \\
\hline Medium NNPAs & B (7I-90\%) (Satisfactory Performance) & $\begin{array}{l}\text { IDBI Bank, Indian Overseas Bank, Syndicate Bank, Oriental Bank of Commerce, Central Bank of India, Bank } \\
\text { of India, United Bank of India, Vijaya Bank. }\end{array}$ \\
\hline \multirow[t]{2}{*}{ Lowest NNPAs } & C (9I-I00\%) (Good Performance) & $\begin{array}{l}\text { Allahabad Bank, Bank of Baroda, Dena Bank, Corporation Bank, Indian Bank, Andhra Bank, Punjab \& Sind } \\
\text { Bank. }\end{array}$ \\
\hline & Group & $2011-2012$ \\
\hline Highest NNPAs & A (I-70\%)(Poor Performance) & $\begin{array}{l}\text { State Bank of India, Central Bank of India, Punjab National Bank, Bank of India, Canara Bank, Union Bank of } \\
\text { India, IDBI Bank. }\end{array}$ \\
\hline Medium NNPAs & B (7I-90\%) (Satisfactory Performance) & $\begin{array}{l}\text { Oriental Bank of India, UCO Bank, Indian Overseas Bank, Bank of Baroda, Indian Bank, Syndicate Bank, } \\
\text { Allahabad Bank. }\end{array}$ \\
\hline \multirow[t]{2}{*}{ Lowest NNPAs } & C (9I-I00\%) (Good Performance) & $\begin{array}{l}\text { United Bank of India, Vijaya Bank, Corporation Bank, Andhra Bank, Dena Bank, Punjab \& Sind Bank, Bank } \\
\text { of Maharashtra. }\end{array}$ \\
\hline & Group & $2012-2013$ \\
\hline Highest NNPAs & A (I-70\%) (Poor Performance) & $\begin{array}{l}\text { State Bank of India, Punjab National Bank, Bank of India, Canara Bank, Central Bank of India, Bank of } \\
\text { Baroda, Allahabad Bank, UCO Bank. }\end{array}$ \\
\hline Medium NNPAs & B (7I-90\%) (Satisfactory Performance) & $\begin{array}{l}\text { Indian Overseas Bank, Union Bank of India, IDBI Bank, Oriental Bank of Commerce, Andhra Bank, Indian } \\
\text { Bank. }\end{array}$ \\
\hline \multirow[t]{2}{*}{ Lowest NNPAs } & C (9I-I00\%) (Good Performance) & $\begin{array}{l}\text { United Bank of India, Corporation Bank, Syndicate Bank, Punjab \& Sind Bank, Dena Bank, Vijaya Bank, Bank } \\
\text { of Maharashtra. }\end{array}$ \\
\hline & Group & $2013-2014$ \\
\hline Highest NNPAs & A (I-70\%) (Poor Performance) & $\begin{array}{l}\text { State Bank of India, Punjab National Bank, Bank of India, Central Bank of India, Bank of Baroda, Canara } \\
\text { Bank, Allahabad Bank, Indian Overseas Bank, Union Bank of India. }\end{array}$ \\
\hline Medium NNPAs & B (7I-90\%) (Satisfactory Performance) & IDBI Bank, United Bank of India, Oriental Bank of Commerce, UCO Bank, Andhra Bank, Corporation Bank. \\
\hline \multirow[t]{2}{*}{ Lowest NNPAs } & C (9I-I00\%) (Good Performance) & Indian Bank, Syndicate Bank, Punjab \& Sind Bank, Dena Bank, Bank of Maharashtra, Vijaya Bank. \\
\hline & Group & 20I4-20I5 \\
\hline Highest NNPAs & A (I-70\%) (Poor Performance) & $\begin{array}{l}\text { State Bank of India, Punjab National Bank, Bank of India, Indian Overseas Bank, Canara Bank, Bank of } \\
\text { Baroda, Union Bank of India, Central Bank of India, UCO Bank. }\end{array}$ \\
\hline Medium NNPAs & B (7I-90\%) (Satisfactory Performance) & $\begin{array}{l}\text { IDBI Bank, Allahabad Bank, Oriental Bank of Commerce, Corporation Bank, Bank of Maharashtra, United } \\
\text { Bank of India, Syndicate Bank. }\end{array}$ \\
\hline \multirow[t]{2}{*}{ Lowest NNPAs } & C(9I-I00\%) (Good Performance) & Andhra Bank, Indian Bank, Dena Bank, Punjab \& Sind Bank, Vijaya Bank. \\
\hline & Group & $2015-2016$ \\
\hline Highest NNPAs & A (I-70\%) (Poor Performance) & $\begin{array}{l}\text { State Bank of India, Punjab National Bank, Bank of India, Canara Bank, Bank of Baroda, Indian Overseas } \\
\text { Bank, IDBI Bank, Union Bank of India. }\end{array}$ \\
\hline
\end{tabular}




\begin{tabular}{|c|c|c|}
\hline Medium NNPAs & B (7I-90\%) (Satisfactory Performance) & $\begin{array}{l}\text { Central Bank of India, UCO Bank, Allahabad Bank, Oriental Bank of Commerce, Corporation Bank, Syndicate } \\
\text { Bank, Bank of Maharashtra. }\end{array}$ \\
\hline \multirow[t]{2}{*}{ Lowest NNPAs } & C (9I-I00\%) (Good Performance) & United Bank of India, Andhra Bank, Indian Bank, Dena Bank, Vijaya Bank, Punjab \& Sind Bank. \\
\hline & Group & $2016-2017$ \\
\hline Highest NNPAs & A (I-70\%) (Poor Performance) & $\begin{array}{l}\text { State Bank of India, Punjab National Bank, Bank of India, IDBI Bank, Canara Bank, Indian Overseas Bank, } \\
\text { Union Bank of India, Bank of Baroda, Central Bank of India. }\end{array}$ \\
\hline Medium NNPAs & B (7I-90\%) (Satisfactory Performance) & $\begin{array}{l}\text { Oriental Bank of Commerce, Allahabad Bank, Corporation Bank, Bank of Maharashtra, UCO Bank, Syndicate } \\
\text { Bank. }\end{array}$ \\
\hline \multirow[t]{2}{*}{ Lowest NNPAs } & C (9I-I00\%) (Good Performance) & Andhra Bank, United Bank of India, Indian Bank, Punjab \& Sind Bank, Vijaya Bank. \\
\hline & Group & $2017-2018$ \\
\hline Highest NNPAs & A (I-70\%) (Poor Performance) & State Bank of India, Union Bank of India, Bank of Baroda, Indian Overseas Bank. \\
\hline Medium NNPAs & B (7I-90\%) (Satisfactory Performance) & $\begin{array}{l}\text { Central Bank of India, Oriental Bank of Commerce, UCO Bank, Corporation Bank, Syndicate Bank, Andhra } \\
\text { Bank, Allahabad Bank. }\end{array}$ \\
\hline Lowest NNPAs & C (9I-I00\%) (Good Performance) & United Bank of India, Bank of Maharashtra, Dena Bank, Indian Bank, Vijaya Bank, Punjab \& Sind Bank. \\
\hline
\end{tabular}

\section{Copyrights}

Copyright for this article is retained by the author(s), with first publication rights granted to the journal. This is an open-access article distributed under the terms and conditions of the Creative Commons Attribution license (http://creativecommons.org/licenses/by/4.0/). 